\title{
Taxonomia do gênero Macropeplus Perkins (Monimiaceae, Monimioideae)*
}

\author{
Inês da Silva Santos ${ }^{1}$ \\ Ariane Luna Peixoto ${ }^{2}$
}

\begin{abstract}
RESUMO
A família Monimiaceae engloba 30 gêneros e cerca de 400 espécies de árvores ou arbustos distribuídos pelas regiões tropicais e subtropicais, especialmente do Hemisfério Sul. Está representada no Brasil por seis gêneros e cerca de 95 espécies, sendo os gêneros mais ricos em espécies Mollinedia e Siparuna. Macropeplus, gênero endêmico do Brasil, ocorre em áreas florestadas nos campos rupestres, cerrados e mata atlântica, acima de $1.000 \mathrm{~m}$ de altitude, nos estados da Bahia, Minas Gerais, Goiás, Distrito Federal, Rio de Janeiro e São Paulo. Desde a sua criação, no final do século passado, e até o presente estudo era considerado monoespecífico e compreendendo oito variedades. O presente estudo reconhece quatro táxons, que foram elevados à categoria de espécie: Macropeplus dentatus (Perkins) I.Santos \& Peixoto, M. friburgensis (Perkins) I.Santos \& Peixoto, M. ligustrinus (Tul.) Perkins e M. schwackeanus (Perkins) I.Santos \& Peixoto. As espécies são distintas predominantemente com base na margem e consistência das folhas bem como na coloração que adquirem quando secas, tanto em campo quanto em laboratório; utilizou-se também, como caracteres diferenciais, comprimento do pedúnculo, do pedicelo, dos lobos florais e o número de estames. M. ligustrinus é a espécie de maior área de distribuição, ocorrendo na Bahia, Minas Gerais, Goiás e Distrito Federal; M. friburgensis é exclusiva da Serra do Mar, no Rio de Janeiro, ocorrendo nos municípios de Nova Friburgo e Teresópolis; $M$. schwackeanus é endêmica de Minas Gerais, ocorrendo na Serra de Ouro Preto e Serra do Caparaó; M. dentatus ocorre na Serra do Mar e na Serra da Mantiqueira, no Rio Janeiro e São Paulo. Durante o presente estudo foram localizadas nove populações no campo: cinco de M. ligustrinus, uma de M. friburgensis e três de $M$. dentatus. Não se pode localizar ainda nenhuma população de $M$. scwackeanus no campo.
\end{abstract}

Palavras-chave: Monimiaceae, Monimioideae, Macropeplus, Taxonomia.

\begin{abstract}
The Monimiaceae family includes 30 genera and about 400 trees or shrubs species distributed in tropical and undertropical regions, mainly in the South Hemisphere. In Brazil, it's represented by 6 genera and about 95 species, Mollinedia and Siparuna are richest genera in species. Macropeplus a brasilian endemic genus, is restricted to high land areas, about a thousand meters of altitude, in stunted sparse forests, topical savannas and Atlantic forests located in the states of Bahia, Minas Gerais, Goiás, Distrito Federal, Rio de Janeiro and São Paulo. Since it's creation, in the end of the last century, and until this work, it was considered monoespecific and an eight-variety genus. The present work recognizes 4 taxons that were raised to specie category: Macropeplus dentatus (Perkins) I. Santos \& Peixoto, M. friburgensis (Perkins) I.Santos \& Peixoto, M. ligustinus (Tul.)

*Parte de dissertação de Mestrado de I. da S. Santos, Museu Nacional, UFRJ. Bolsista de pós-graduação da Capes.

${ }^{1}$ Estagiária no Departamento de Botânica da Universidade Federal Rural do Rio de Janeiro. Caixa Postal 74582, 23851-970 Seropédica, RJ. email: inesan@ufrrj.br

2 Departamento de Botânica da Universidade Federal Rural do Rio de Janeiro. Caixa Postal 74582, 23851-970. Seropédica, RJ. Bolsista de Produtividade em Pesquisa do CNPq. email: alpeixoto@ terra.com.br

Endereço para correspondência: UFRRJ, Departamento de Botânica. Caixa Postal 74582, 23851-970. Seropédica, RJ
\end{abstract}


Perkins and M. schwackeanus (Perkins) I.Santos \& Peixoto. The species are mainly distinct by leaves' border consistence, as well as the dry leaves coloration, obtained in field or in laboratory. The floral laps length, the number of stames and the peduncle and pedicel length were also considered. M. ligustrinus the most distributed specie, occurring at Bahia, Minas Gerais, Goiás and Distrito Federal; M. friburgensis is restricted to Serra do Mar in the state of Rio de Janeiro, occurring at Nova Friburgo and Teresópolis municipal districts; M. schwackeanus is endemic of the state of Minas Gerais, occurring at Serra de Ouro Preto and Caparaó; M. dentatus occurs at Serra do Mar and Serra da Mantiqueira, in the states of Rio de Janeiro and São Paulo. During the present work 9 field populations were located: 5 of $M$. ligustrinus, 1 of $M$. friburgensis and 3 of M. dentatus. No $M$. schwackeanus population can still be located in field.

Keywords: Monimiaceae, Monimioideae, Macropeplus, Taxonomy.

\section{INTRODUÇÃO}

Monimiaceae sensu lato, é composta por cerca de 30 gêneros e 400 espécies de árvores ou arbustos, raramente plantas escandentes, distribuídas nas regiões tropicais e subtropicais, especialmente no Hemisfério Sul, sendo o SulSudeste do Brasil e o Arquipélago Malaio os principais centros de dispersão (Hutchinson, 1964; Barroso et al. 1978). No Brasil ocorrem seis gêneros e cerca de 95 espécies (Peixoto et al. ined.b), sendo Siparuna Aublet e Mollinedia Ruiz \& Pav. os mais numerosos.

A família foi tratada do ponto de vista taxonômico por Jussieu (1809), Tulasne (1857), Perkins (1898), Perkins \& Gilg (1901), Hutchinson (1964), que de modo geral a subdividiram em subfamílias, englobando tribos e gêneros reconhecidamente de difícil interpretação e de afinidades filogenéticas mais ou menos estreitas (Peixoto, 1987; Lorence, 1985). Segundo Cronquist (1981), a família engloba quatro subfamílias: Monimioideae, Atherospermoideae, Hortonioideae e Siparunoideae, constituindo-se em um grupo reconhecidamente polifilético. Schodde (1970), com base em caracteres morfológicos, propôs a elevação de Siparunoideae à categoria de família, estabelecendo assim Siparunaceae. Renner (1998) e Renner \& Zanis (ined.), com base principalmente em evidências moleculares, mostraram a estreita afinidade de Monimiaceae sensu str. com Lauraceae e de Siparunaceae com Atherospremataceae.

Evolutivamente a morfologia floral de Monimiaceae é expressa geralmente em termos de redução, tanto em tamanho quanto em número de partes florais; em reestruturação da orientação dessas partes de espiral para radial e finalmente decussado; no fechamento do receptáculo das flores femininas; em transição de carpelos livres para um gineceu sincárpico e ínfero (Corner, 1976; Lorence, 1985). Outras características da anatomia da madeira, do grão de pólen, da arquitetura da folha e da progressão de monoecia para dioecia também foram assinaladas por Lorence (1985).

Na família algumas espécies se destacam pela importância econômica, principalmente, no uso medicinal, pela presença de óleos voláteis aromáticos (Leitão et al. 1999). Peumus boldus Molina (boldo-do-chile), espécie endêmica do Chile, é largamente empregada em muitos lugares do mundo para transtornos hepáticos e como anti-inflamatórios, pela presença de boldina e de óleos essenciais (Peixoto et al., ined.a).

A monografia dePerkins \& Gilg (1901), é o trabalho mais abrangente sobre a família, no qual todos os gêneros conhecidos até então são tratados e propostos novos táxons, entre os quais Macropeplus Perkins. Os autores apresentam chaves para identificação de todas as categorias taxonômicas.

A subfamília Monimioideae como tratada por Perkins \& Gilg (1901), compreende 26 gêneros de relacionamento relativamente estreito (Money et al. 1950; Phillipson, 1980) distribuídos nas tribos Hortonieae, Trimenieae, Monimieae e Mollinedieae. Está representada 
nos trópicos por cinco gêneros: Mollinedia Ruiz \& Pav., Hennecartia Poiss., Macrotorus Perkins, Peumus Moll. e Macropeplus Perkins. As Mollinedieae retratam, através da morfologia, um relacionamento filogenético estreito entre os seus membros, sendo possível traçar um caminho de derivação de caracteres, mesmo estando o grupo, hoje, disperso em áreas não conectadas (Peixoto 1987).

No Brasil, estudos para um melhor conhecimento das Monimiaceae foram realizados por Tulasne (1857), na Flora Brasiliensis; por Peixoto com o gênero Hennecartia (1976) e com o gênero Mollinedia $(1979,1987)$. Trabalhos em floras regionais foram realizados por Pereira (1991), que estudou as espécies de Siparuna do Estado do Rio de Janeiro; a família foi estudada por Giulietti (1971), para o Distrito Federal; por Peixoto (1983), para o Parque Estadual das Fontes do Ipiranga, São Paulo; por Giulietti \& Pirani (1995), para o Pico das Almas, Bahia; por Peixoto \& Pereira-Moura (1996), para a Reserva Ecológica de Macaé de Cima, Rio de Janeiro; por Peixoto et al. (ined. a), para Santa Catarina; por Peixoto et al. (ined. b), para o Estado de São Paulo; por Pereira-Moura e Peixoto (ined.) para Grão Mogol, Minas Gerais.

Macropeplus Perkins é um gênero exclusivamente brasileiro que habita florestas ou capões de mata em campos rupestres, cerrados, mata atlântica alto-montana e transição para os campos de altitude, no Sudeste, Centro Oeste e Nordeste. São plantas arbustivas ou árvores de pequeno porte, mais raro árvores de porte médio, dióicas, com flores pequenas, brancas, amareladas a esverdeadas, monoclamídeas, com quatro lobos caliciniais maiores do que o tubo do cálice, e grande número de carpelos e estames dispostos no fundo do receptáculo.

Após a descrição do gênero monoespecífico e a caracterização de oito variedades por Perkins, em 1898, e o tratamento dado em Perkins \& Gilg, em 1901, Macropeplus foi referido em Vattimo (1957),
Giulietti (1971), Giulietti \& Pirani (1995), Peixoto \& Pereira-Moura (1996) e PereiraMoura \& Peixoto (ined.). De modo geral o gênero está pouco representado nos herbários brasileiros e nos grandes herbários do exterior, frequientemente apenas pelos exemplares dos tipos das variedades ou por coleções clássicas feitas no século passado.

Tendo em vista que um estudo abrangente revisando o gênero se fez necessário, objetivouse, neste trabalho, reavaliar a classificação infraespecífica vigente, localizar populações no campo para complementar dados morfológicos dos táxons, enriquecer e atualizar as coleções de herbário, criando assim possibilidades para que estudos em outros campos do conhecimento (especialmente em química de produtos naturais, palinologia e anatomia), com táxons do gênero, possam ser iniciados.

Do ponto de vista biológico Monimiaceae é reconhecidamente uma família chave para a compreensão dos grupos primitivos de angiospermas (Lorence, 1985, Peixoto, 1987). Do ponto de vista econômico a família é especialmente empregada nos diversos locais onde ocorre, pelas populações locais, como tônico, estimulante, digestivo e carminativa e contra males gastrointestinais, respiratórios, febres, reumatismo, doenças de pele e mordidas de cobra. Leitão et al. (1999), em estudo químico e farmacológico sobre a família, particularmente com espécies brasileiras de Siparuna e Mollinedia, afirmam que a família é rica em alcalóides benzilisoquinolínicos, especialmente apomorfinas e oxoapomorfinas. Citam como flavonóides mais comuns os derivados de kaempferol e glicosilatados ou methoxylatados, estes últimos menos comuns.

Garrat (1934) comenta que a presença de grande quantidade de óleo volátil, na maioria das Monimiaceae lhes distinguem por meio de um agradável odor, e algumas são tidas como de valor medicinal. Peumus boldus (boldo-dochile) é a espécie de Monimiaceae mais empregada na produção de medicamentos preparados com os extratos foliares, para transtornos hepáticos e como anti-inflamatórios, 
pela presença de boldina e de óleos essenciais (Peixoto et al. ined. a).

No Brasil, Siparuna apiosice, conhecida como "limão-bravo", é a espécie mais largamente empregada, tanto em forma de infusão de suas folhas, como constituinte de xaropes contra males respiratórios (Kuhlmann \& Kühn, 1947, Stellfeld, 1955) e usada também no tratamento de distúrbios intestinais. Está descrita na primeira farmacopéia brasileira (Dias da Silva, 1926) e incluída na Farmacopéia Paulista (Stellfeld, 1955). Siparuna guianensis é utilizada por índios amazônicos, em forma de chá, para doenças reumáticas (Prance, 1972), e tem suas folhas empregadas também contra cólicas, sendo citada por Kuhlmann \& Kühn (1947) como tóxica para animais. Mollinedia schottiana (como $M$. brasiliensis) foi citada por Corrêa (1978) como antiespasmódica, e vem sendo comercializada em feiras livres do sudeste brasileiro, com indicação para males do estômago e para banhos (Peixoto et al. indet.a). Diversas espécies de Mollinedia e Siparuna fazem parte da dieta alimentar de aves, morcegos e macacos. Doryphora sassafras, é utilizada em perfumaria (Perkins \& Gilg, 1901).

Mollinedia schottiana (Spreng.) Perkins, o capixim, é citada por Record \& Hess (1943), como fornecedora de uma madeira flexível, usada na fabricação de barril e bordas de peneiras e por Peixoto et al. (ined.a) como fornecedora de lenha e madeira para diversas utilidades.

Os gêneros Mollinedia e Siparuna, têm algumas espécies estudadas dos pontos de vista químico e farmacológico por pesquisadores do Laboratório do Núcleo de Pesquisa de Produtos Naturais (NPPN) da Universidade Federal do Rio de Janeiro (UFRJ), coordenados pela Dra. Gilda G. Leitão. Cinco espécies de Mollinedia foram estudadas (M. schottiana, M. glaziovii, $M$. salicifolia, M. marliae e M. uleana) e três de Siparuna (S. arianeae, $S$ apiosyce e $S$. guianensis)
Sobre o gênero Macropeplus, embora se tenha procurado, não se obteve em campo informações sobre o seu uso sendo assim, provavelmente não tenha ainda sido empregado pelos moradores das áreas onde as espécies ocorrem. Fitoquimicamente também ainda não foi estudado. Estratos de suas folhas, estão sendo trabalhado pela equipe coordenada pela Dra. Gilda G. Leitão.

\section{HISTÓRIA TAXONÔMICA DO GÊNERO MACROPEPLUS PERKINS}

A história taxonômica de Monimiaceae têm início a quase dois séculos, quando Jussieu, fundou a família como Monimieae, em 1809, baseado em três gêneros já anteriormente descritos: Monimia P.Th., Atherosperma Labill. e Citrosma Ruiz \& Pav.

Tulasne (1855), redescreveu a família, incluiu nela mais sete gêneros e elaborou uma chave para separar os 10 gêneros então estabelecidos: Ambora Juss., Monimia P.Th., Citriosma Ruiz \& Pav., Mollinedia Ruiz \& Pav., Kibara Endl., Hedycarya Frst., Boldea Juss., Laurelia Juss., Atherosperma Labill. e Doryphora Endl. Nesta chave subdividiu a família em 3 grupos (tribos), baseando-se no receptáculo frutífero. O primeiro grupo Sycioideae (Amboreae) com o gênero Ambora Juss.; o segundo grupo Drupaceae (Monimieae) subdividido em dois grupos menores, conforme o perigônio - Cryptocarpae com os gêneros Monimia P.Th., Citriosma Ruiz. \& Pav., separando-os de acordo com os óvulos e Gymnocarpae com os gêneros Mollinedia Ruiz \&. Pav., Kibara Endl., Hedycarya Frst. e Boldea Juss., separados de acordo com o comprimento das tépalas e número de estames. O terceiro grupo Archaeniophorae (Atherospermeae) com os gêneros Laurelia Juss., Atherosperma Labill., Doryphora Endl., separados com base no receptáculo.

A tribo Monimieae (Drupaceae), foi desmembrada em várias seções. A seção Mollinediae constando entre outros, do gênero Mollinedia Ruiz \& Pav. incluindo entre suas 
espécies, Mollinedia ligustrina Tul. cuja descrição vem acompanhada de uma ilustração.

Em 1857, Tulasne, na Flora Brasiliensis, redescreve a família e apenas os gêneros brasileiros: Citriosma Ruiz \& Pav. (atualmente Siparuna) com 26 espécies e Mollinedia Ruiz \& Pav. com 16 espécies, separando-os por seus óvulos pêndulos ou eretos. Neste trabalho Mollinedia ligustrina Tul. foi também descrita e ilustrada.

Pax (1891), propõe duas subfamílias, Monimioideae e Atherospermoideae e cria seis tribos. Monimioideae com três tribos: Hortonieae, Hedycarieae e Monimieae, segundo o tipo de carpelo e Atherospermoideae com outras três: Laurelieae, Atherospermeae e Siparuneae. O gênero Mollinedia Ruiz \& Pav. (no qual até então está incluído Macropeplus Perkins) é incluído na tribo Hedycarieae.

Bentham \& Hooker (1883), reconhecem apenas duas tribos: Monimieae e Atherospermeae, baseados em características das anteras e óvulos.

Em 1896, Taubert descreve a espécie Mollinedia pyrenea a partir da coleta de Ule de número 31182, feita na cabeceira do rio das Pedras, na Serra dos Pirineus, em Goiás.

Perkins (1898), concorda com o sistema adotado por Pax, conservando as duas subfamílias e a separação da subfamília Monimioideae nas seções Hortonieae, Hedycarieae e Monimieae. Propõe uma nova seção: Mollinedieae com 10 gêneros separados em dois grupos: um com plantas dióicas, ocorrentes nos trópicos do Novo Mundo e outro com plantas monóicas ocorrentes na região Indo-Malaia, Austrália e Madagascar. Descreve neste trabalho os gêneros Macropeplus, Macrotorus, Steganthera, Anthobembix e Tetrasynandra. Os dois primeiros a partir de espécies do gênero Mollinedia Ruiz \& Pav., fazendo uma nova combinação para Mollinedia ligustrina Tul., transferindo-a para o novo gênero Macropeplus, resultando em Macropeplus ligustrinus (Tul.) Perkins. Reconhece oito variedades (schwackeana, xylophylla, rhomboideae, pohlii, typica, friburgensis, dentata e grandiflora).

Em 1901, Perkins \& Gilg realizam um amplo trabalho sobre a família. Reconhecem as duas subfamílias propostas por Pax, mas modificam as tribos. Monimioideae é subdividida em quatro tribos, Hortonieae, Trimenieae, Mollinedieae e Monimieae, separadas com base na forma do receptáculo, nas tépalas das flores femininas e no número de carpelos. Atherospermoidae foi separada nas tribos Laurelieae e Siparunieae. O gênero Macropeplus Perkins foi incluído na tribo Mollinedieae, juntamente com os gêneros Macrotorus Perkins e Mollinedia Ruiz \& Pav. Neste trabalho, os autores redescreveram Macropeplus Perkins e suas variedades. Reproduzem a mesma ilustração publicada em Perkins (1898). A variedade grandiflora, descrita em 1898 por Perkins, é tratada como sinônimo da variedade pyrenea Perkins resultante de uma nova combinação de Mollinedia pyrenea Taub. descrita anteriormente por Taubert (1896).

Em 1911, Perkins apresenta uma estampa do gênero acrescentando, aos detalhes já apresentados anteriormente, um desenho do hábito e da infrutescência.

Glaziou em 1913, em sua Liste de Plantes $d u$ Brésil Central cita as variedades friburgensis Perkins, dentata Perkins, grandiflora Perkins e xylophylla Perkins, coletadas por ele, e os vários herbários onde estão depositados os tipos.

Em 1964, Hutchinson, baseando-se em Bentham \& Hooker (1883), redescreve a família, subdividindo-a em duas subfamílias, reconhecendo apenas quatro tribos. Apresenta uma chave para as subfamílias, tribos e gêneros e os descreve, dando também a distribuição geográfica e propriedades econômicas. No arranjo dado à família, considera na subfamília Monimioideae, as tribos Hedycaryeae e Monimieae e na subfamília Atherospermoideae as tribos 
Tabela 1. Variedades descritas para Macropeplus ligustrinus (Tul.) Perkins, coletores dos exemplares-tipos, seus números, herbários depositários e localidades de coleta.

\begin{tabular}{|c|c|c|}
\hline Variedade & $\begin{array}{c}\text { Coletor e número } \\
\text { (herbário } \\
\text { depositário) }\end{array}$ & Localidade típica \\
\hline Macropeplus ligustrinus var. dentata & $\begin{array}{l}\text { Glaziou } 17222 \text { (C!) } \\
\text { Glaziou } 4203 \text { (BM! } \\
\text { C!) } \\
\text { Glaziou } 11551 \text { (BR! } \\
\text { C!) } \\
\text { Moura s.n. (?) }\end{array}$ & $\begin{array}{l}\text { RJ, Serra dos Órgãos } \\
\text { RJ, Serra dos Órgãos } \\
\text { SP, Serra da Bocaina } \\
\text { RJ, Teresópolis }\end{array}$ \\
\hline $\begin{array}{l}\text { Macropeplus ligustrinus var. } \\
\text { friburgensis }\end{array}$ & $\begin{array}{l}\text { Glaziou } 17769(\mathrm{C} !) \\
\text { Glaziou } 20485(\mathrm{BR} ! \\
\mathrm{K} !)\end{array}$ & $\begin{array}{l}\text { RJ, Nova Friburgo, Macaé de } \\
\text { Cima } \\
\text { RJ, Nova Friburgo, Macaé de } \\
\text { Cima }\end{array}$ \\
\hline Macropeplus ligustrinus var. pohlii & Pohl 3561 (BR) & Sem localidade \\
\hline $\begin{array}{l}\text { Macropeplus ligustrinus var. pyrenea } \\
\text { (= var. grandiflora) }\end{array}$ & $\begin{array}{l}\text { Glaziou } 22040(\mathrm{BR} ! \\
\text { C! K! RB!) } \\
\text { Ule } 3182(\mathrm{~B})\end{array}$ & $\begin{array}{l}\text { GO, Rio das Pedras } \\
\text { GO, Serra dos Pirineus }\end{array}$ \\
\hline Macropeplus ligustrinus var. rhomboidea & Sellow 1037 (B) & Sem localidade \\
\hline $\begin{array}{l}\text { Macropeplus ligustrinus var. schwackeana } \\
\text { Macropeplus ligustrinus var. typica }\end{array}$ & $\begin{array}{l}\text { Schwacke } 7465 \\
(\text { RB! BHCB!) } \\
\text { Sellow } 1122 \text { (B) }\end{array}$ & $\begin{array}{l}\text { MG, Ouro Preto, Itacolomi } \\
\text { Sem localidade }\end{array}$ \\
\hline Macropeplus ligustrinus var. xylophylla & $\begin{array}{l}\text { Glaziou } 18482(\mathrm{C} ! \\
\text { K!) } \\
\text { Ule } 2441(\mathrm{R} !)\end{array}$ & $\begin{array}{l}\text { MG, Ouro Preto, Itacolomi } \\
\text { MG, Ouro Preto, Itacolomi }\end{array}$ \\
\hline
\end{tabular}


Laurelieae e Atherospermeae. Macropeplus fica submetido a subfamília Monimioideae e a tribo Hedycaryeae.

Barroso et al. (1978), dão a família um tratamento taxonômico, em que apenas os gêneros brasileiros são retratados, com uma chave para identificação das subfamílias, tribos e gêneros. Macropeplus Perkins é mantido na tribo Hedycaryeae, como proposto por Hutchinson (1964).

Giulietti (1971), em trabalho sobre as Monimiaceae do Distrito Federal, faz estudo sistemático de espécies de Siparuna Aubl. e Macropeplus Perkins.

Giulietti \& Pirani (1995), na Flora do Pico das Almas, tratam de Monimiaceae, que se fez representar na área por Macropeplus ligustrinus (Tul.) Perkins, que ocorre nas matas ripárias com populações numerosas.

Peixoto \& Pereira-Moura (1996), estudam as Monimiaceae da Reserva Ecológica de Macaé de Cima, em Nova Friburgo, Rio de Janeiro, onde a família esta representada por 15 espécies de Mollinedia Ruiz \& Pav., uma espécie de Siparuna e Macropeplus ligustrinus (Tulasne) Perkins com a variedade friburgensis.

Peixoto et al. (ined.b), na Flora Fanerogâmica do Estado de São Paulo tratam de cinco gêneros da família, incluindo um total de 30 espécies, Macropeplus se fazendo representar pela variedade dentata.

Pereira-Moura \& Peixoto, na flora de Grão Mogol (no prelo) tratam de duas espécies da família, Siparuna espinhacensis e Macropeplus ligustrinus (Tulasne) Perkins.

Renner (1998) com base em seqüenciamento de gens (seqüência de nucleotídeos de cloroplasto $r b c L$ e espaçamento intergênico trnL-trnF) tratou das afinidades filogenéticas de Monimiaceae. Exclui diversos táxons da família, reconhecendo no Novo Mundo os gêneros Mollinedia (incluindo Macrotorus e Macropeplus, não incluído na sua análise) e Hennecartia em um clado e Peumus em outro. Renner \& Zanis (ined.) tratando da filogenia de Monimiaceae circunscrevem a família com 25 gêneros e 200 espécies, reconhecendo Macropeplus e Macrotorus embora ainda não estudados do ponto de vista do seqüenciamento genético. A tabela 1 mostra as variedades até então conhecidas, a localidade típica das mesmas, o coletor do tipo e o herbário depositário.

\section{MATERIAIS E MÉTODOS}

O estudo foi realizado nas dependências do Departamento de Botânica da Universidade Federal Rural do Rio de Janeiro (UFRRJ), onde contou-se com as facilidades oferecidas por este Departamento. Baseou-se em pesquisa bibliográfica, consulta e análise de material de herbário e em coletas e observações realizadas em campo. O levantamento bibliográfico abrangeu as obras relacionadas ao gênero Macropeplus e obras clássicas que tratassem a família Monimiaceae, a subfamília Monimioideae e a tribo Mollinedieae. Outras publicações foram consultadas, principalmente aquelas sobre geografia e relatos dos naturalistas viajantes do século XIX, com a finalidade de se descobrir as localidades de ocorrência das variedades, entre as quais destacam-se Viagem pelo Brasil, de Spix \& Martius (1938) e o volume I da Flora Brasilensis, editado por Urban (1906), que reúne detalhes sobre as coletas de alguns naturalistas, entre os quais Glaziou, Pohl, Schwacke, Sellow e Ule coletores de exemplares-tipo de Macropeplus.

Foram estudados materiais botânicos recebidos, como empréstimo, de herbários nacionais e estrangeiros e de herbários nacionais visitados, listados a seguir, em ordem alfabética de suas siglas designativas, segundo Holmgren et al. (1990), atualizado em página web http://www.nybg.org/bsci/ih/ih.html. Os herbários visitados encontram-se assinalados com asterisco $\left(^{*}\right)$; B, BHCB, BM, BR, C, CEN, CEPEC, CESJF *, F, FCAB *, GUA *, HAL, HEPH *, HRB *, HUEFS, IAC, IBGE, K, M, MO, NY, OUPR, PR, R*, RB , RBR , SJRP, SPF, SPSF, UB , UEC*, US, VIC*, W, Z. 
Os herbários Botanischer Garten und Botanisches Museum, Berlin-Dahlen (B) e Naturhistorishes Museum Wien, Áustria (W) responderam ao pedido de empréstimo de exemplares-tipo, informando que não dispunham mais destes exemplares, pois os mesmos foram destruídos durante a Segunda Guerra Mundial. Cinco outros herbários foram visitados e não dispunham de exemplares do gênero (ALCB, PNI, RUSU, RFA, RBE).

Buscou-se realizar expedições às localidades de ocorrência dos táxons do gênero, especialmente às localidades dos tipos, visando a observação de suas populações em seu habitat natural, fazer registros fotográficos e coletar exemplares para herbário, fixando também, em álcool $70^{\circ} \mathrm{Gl}$, partes vegetativas e florais. As localidades dos tipos dos táxons estão hoje, em sua maioria, em Unidades de Conservação. Assim foram realizadas excursões às seguintes localidades: Fazenda Água Limpa-Universidade Federal de Brasília, DF; Jardim Botânico de Brasília, DF; Parque Estadual de Campos do Jordão, Município de Campos do Jordão, SP; Pedra do Bauzinho, São Bento do Sapucaí, SP; São José dos Alpes, Campos do Jordão, SP; Parque Nacional do Itataia, Itatiaia, RJ; Pedra do Sino, Parque Nacional da Serra dos Órgãos, Município de Teresópolis, RJ; Pico das Almas, Município de Rio de Contas, BA; Serra de Grão Mogol, Município de Grão Mogol, MG; Serra de Ibitipoca, Parque Estadual de Ibitipoca, Município de Lima Duarte, MG; Serra do Cipó, Parque Nacional da Serra do Cipó, Município de Cardeal Mota e arredores, MG; Serra do Caraça, Parque Natural do Caraça, Município de Santa Bárbara, MG.

No texto as obras encontram-se citadas segundo Stafleu \& Cowan (1979) e os periódicos seguem Lawrence (1968). Para a abreviatura do nome dos autores dos binômios seguiu-se Brumitt \& Powell (1992). A classificação do padrão de venação segue Hickey (1973). Para a classificação dos tipos de vegetação seguiu-se, de modo geral, Rizzini (1979), complementado por estudos específicos das áreas de ocorrência dos táxons, quando disponíveis. Os dados sobre a distribuição geográfica, habitat, ecologia e fenologia foram obtidos através de informações contidas em etiquetas de material herborizado e observações de campo feitas durante as expedições. As ilustrações foram confeccionadas com o auxílio de estereomicroscópio marca Wild M-5, com câmara clara acoplada. A organização do texto e citação do material examinado segue, de modo geral, as recomendações contidas em "A Guide for Contributors to Flora Neotropica" de 1997, também disponível em página web, na internet (http://www.nybg.org/bsci/ofn/ ofn.html). Citou-se os autores dos gêneros apenas no tratamento histórico. Optou-se pela não indicação de lectotipos nos sinônimos, embora este procedimento tenha sido seguido, quando necessário, nas espécies válidas. As abreviaturas empregadas e seus significados são: "fl mas" - flor masculina, "fl fem " - flor feminina, "fr" - frutificação, " fr im" -fruto imaturo, "st" - planta estéril, "s.l." - sem localidade, "s.d." - sem data de coleta e "s.n." - sem número de coletor, "ind." - indivíduo.

\section{RESULTADOS E DISCUSSÃO}

Observação: $O$ tratamento aqui dado ao gênero considera-o como englobando quatro espécies. Assim, na apresentação e discussão dos resultados, desde seu início, os táxons serão assim denominados.

\section{Aspectos Morfológicos}

HÁBITO: As espécies de Macropeplus são arbustos ou arvoretas dióicas, com alturas que variam de 1,5 a $15 \mathrm{~m}$. $M$. dentatus e $M$. friburgensis, têm hábito arbóreo, esta última podendo alcançar até $15 \mathrm{~m}$ de altura. $M$. schwackeanus e M. ligustrinus são arbustos ou arvoretas, com altura, de modo geral, em torno de $2,5 \mathrm{~m}$. O caule é cilíndrico, acinzentado, muito ramificado. Os ramos são estriados, lenticelados, quando jovens, vináceos. Observou-se, com muita freqüência, na base dos ramos férteis, diversas ramentas 

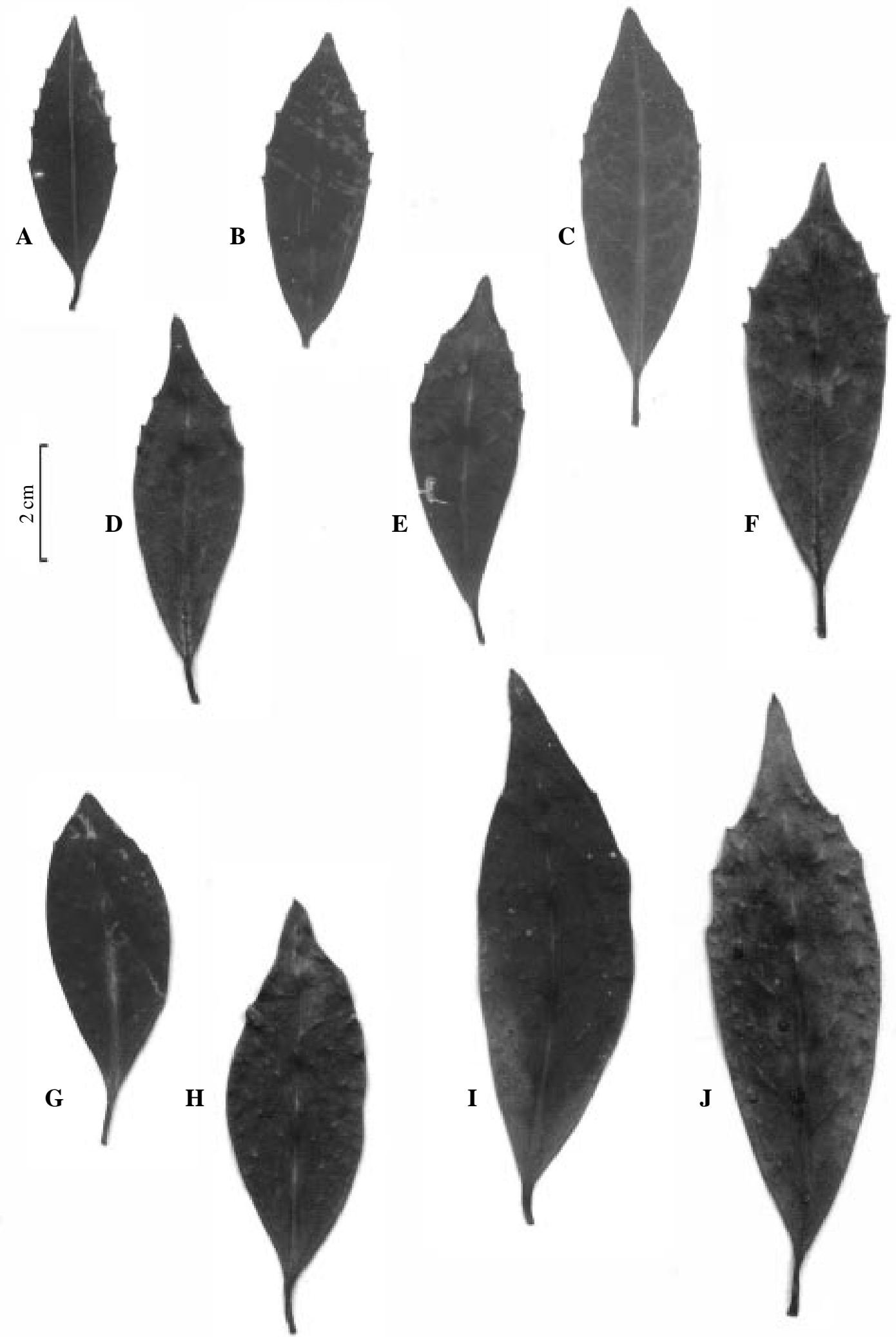

Figura 1. Variação foliar em Macropeplus dentatus (A-F) e M. friburgensis (G-J).

Rodriguésia 52(81): 65-105. 2001 


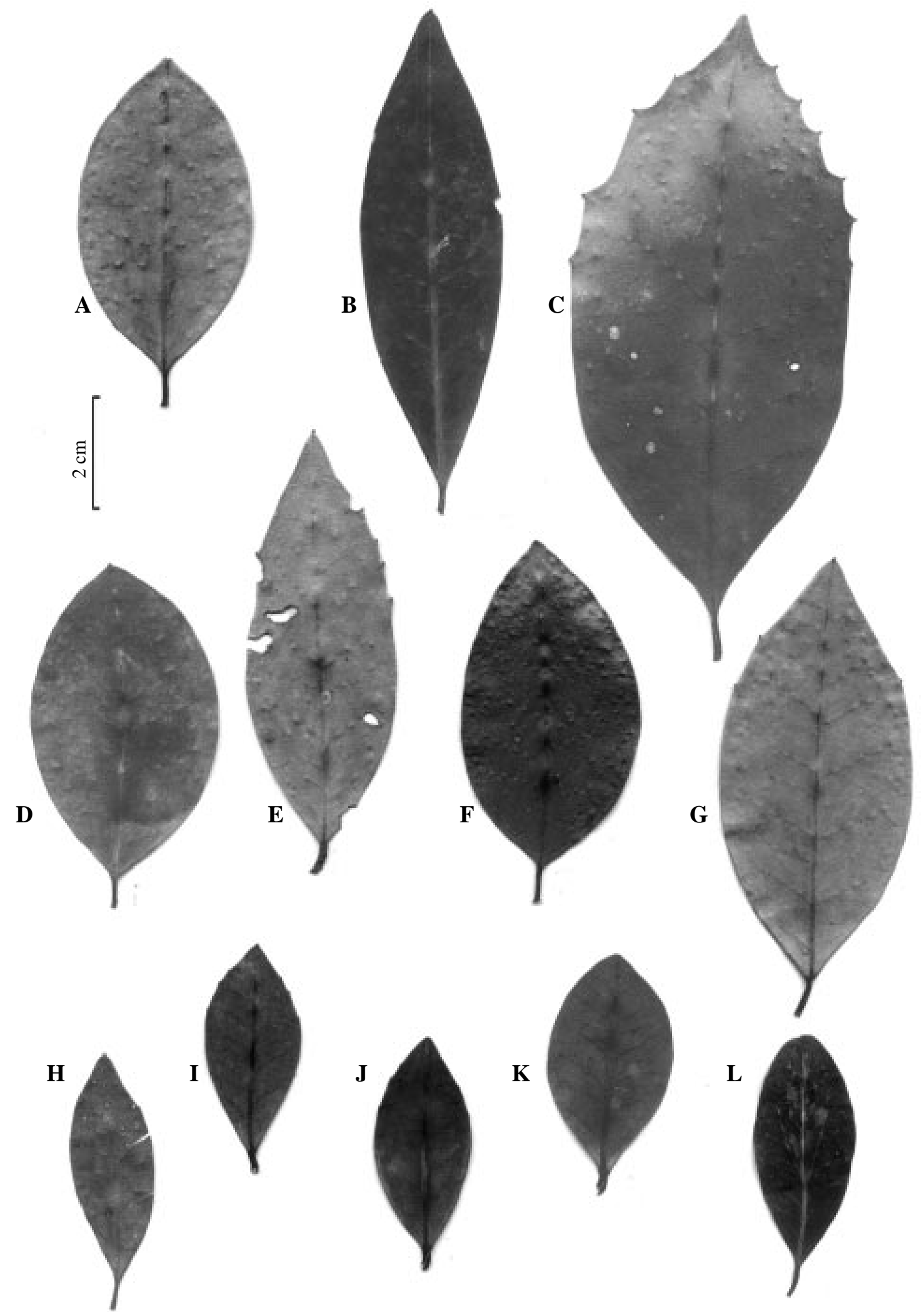

Figura 2. Variação foliar em Macropeplus ligustrinus (A-G) e M. schwackeanus (H-L). 
dispostas congestamente. M. ligustrinus apresenta ramos escandentes (Fig. 4 a-d) TRICOMAS: As plantas são glabras, exceto as brácteas, bractéolas e parte interna das flores femininas. De modo geral tricomas simples e pluricelulares ocorrem na região mediana e no bordo das brácteas e na face interna das bractéolas; nas flores femininas cobrem, internamente, o receptáculo floral, e os carpelos.

FOLHAS: As folhas são opostas e decussadas, glabras, elípticas, elípticolanceoladas, oblongo-lanceoladas, lanceoladas, ovadas ou rombóides (Figs. 1, 2 e 5 a,b). Há uma grande variação no tamanho e na forma, até num mesmo ramo. O ápice é agudo, apiculado ou acuminado, ocorrendo com menor frequiência o ápice obtuso. A base é aguda em todas as espécies. M. schwackeanus apresenta as margens foliares inteiras; $\operatorname{Em} M$. friburgensis e $M$. ligustrinus as margens são inteiras ou, raro, com poucos e irregulares dentes. Já em $M$. dentatus as folhas têm as margens tipicamente dentadas. De modo geral são nítidas e mesmo após secagem apresentam um certo brilho. A textura pode variar de muito rígida, em $M$. schwackeanus a membranácea em M. ligustrunus.

O padrão de venação comum às espécies é o camptódromo-broquidódromo. As nervuras secundárias são de 7-11 pares e variam de opostas a subopostas; são caracteristicamente promínulas na face abaxial.M. schwackeanus se destaca pelas nervuras mais proeminentes na face abaxial que as demais espécies, além de apresentar suas folhas, de modo geral pequenas, de textura rígida, coriácea, que, quando desidratadas se tornam enegrecidas. M. ligustrinus se destaca, quando herborizada, por apresentar as lâminas foliares acastanhadas, mais raro verde-oliva. $M$. friburgensis, de modo geral toma a coloração esverdeada após o processo de desidratação.

Os pecíolos são vináceos (Fig.5h), cilíndricos, com a face superior canaliculada. M. schwackeanus é a mais curtamente peciolada, com pecíolo de 3-5 $\mathrm{mm}$, seguida por
M. dentatus com 3-9 mm; pecíolos mais longos são encontrados em $M$. friburgensis, 6-10 mm e M. ligustrinus apresenta a maior variação, de modo mais geral alcançando de 5-10 $\mathrm{mm}$, mas com extremos desde $3 \mathrm{~mm}$ até $18 \mathrm{~mm}$.

Lorence (1985), comentando sobre as folhas de Monimia, gênero exclusivo de Madagascar, diz que embora as formas gerais extremas pareçam ser muito distintas, tamanho e forma no gênero não provêem características taxonômicas estáveis o mesmo ocorrendo com características do ápice (acuminado, agudo ou obtuso). As mesmas variações foram encontradas em Macropeplus. Ao tamanho e forma foliar outras características são necessárias no processo de identificação das espécies e suas populações, entre as quais destacam-se a consistência e a coloração que adquirem após o processo de secagem (no campo, as folhas secas no solo, ou após o processo de herborização).

INFLORESCÊNCIA: A inflorescência básica é uma tríade, entretanto a sua estrutura é bastante variável (Figs. 3 e 5c,f,g). A inflorescência masculina geralmente é multiflora, em tríades simples (3 flores apenas) ou tríades organizadas em tirsos (até 24 flores). As inflorescências femininas sofrem redução, de modo geral apresentando-se em monocásio, mais raro como pleiocásio (Fig..5g) As tríades são opostas, decussadas, subtendidas por uma bráctea, de início verde, depois amarronzada e caduca. As duas flores laterais da tríade são subtendidas por bractéolas.

A posição da inflorescência de modo geral é axilar, mais raro extra-axilar (entre dois nós) ou terminais, neste caso o ramo continua crescendo após a floração e a inflorescência é então folhosa. A estrutura das inflorescências segue um padrão semelhante ao encontrado em Mollinedia por Peixoto (1987) e em algumas espécies de gêneros da Região Malasiana, por Lorence (1985), estes, entretanto acomodando uma variação de formas muito maior. 

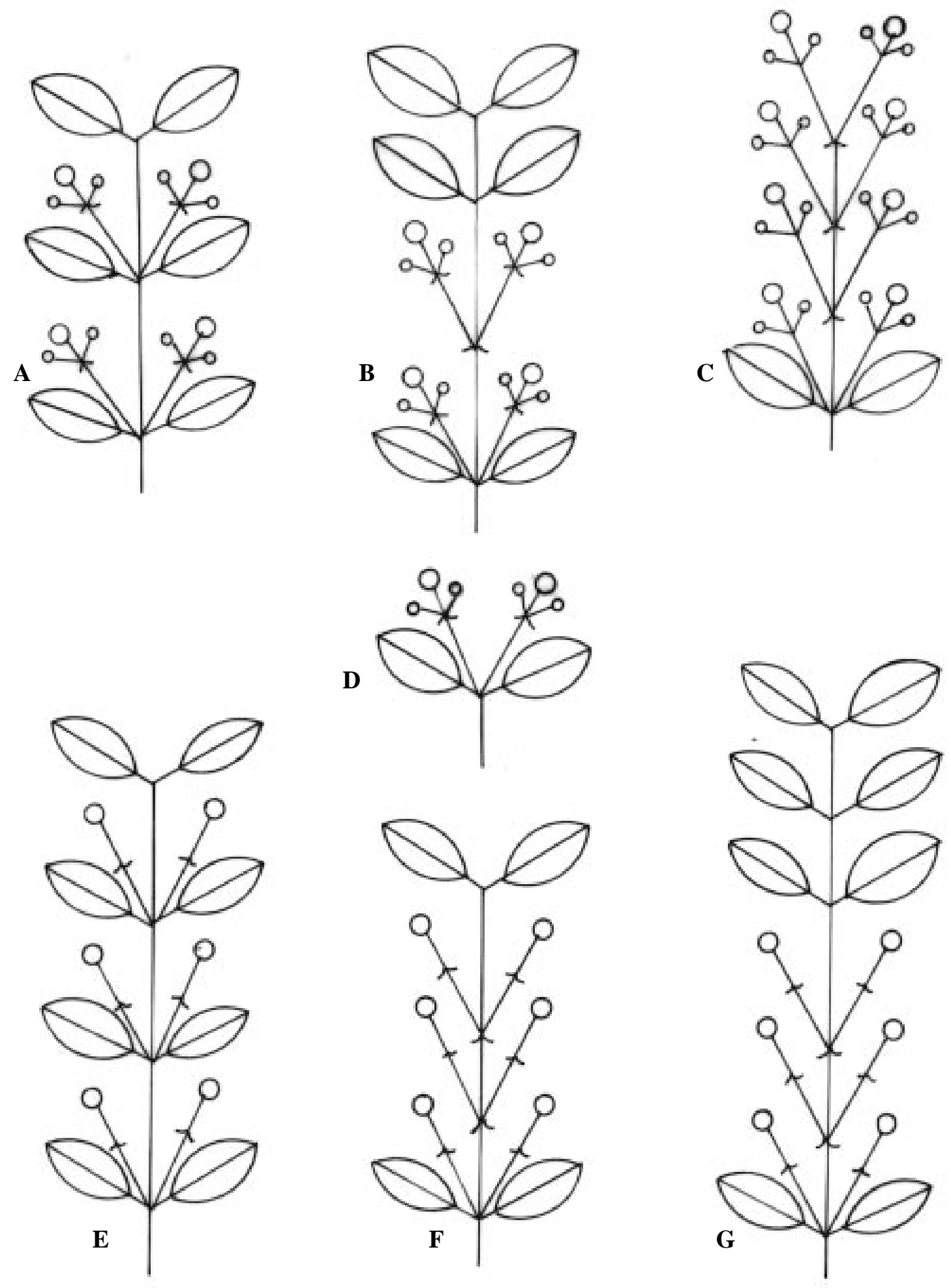

D
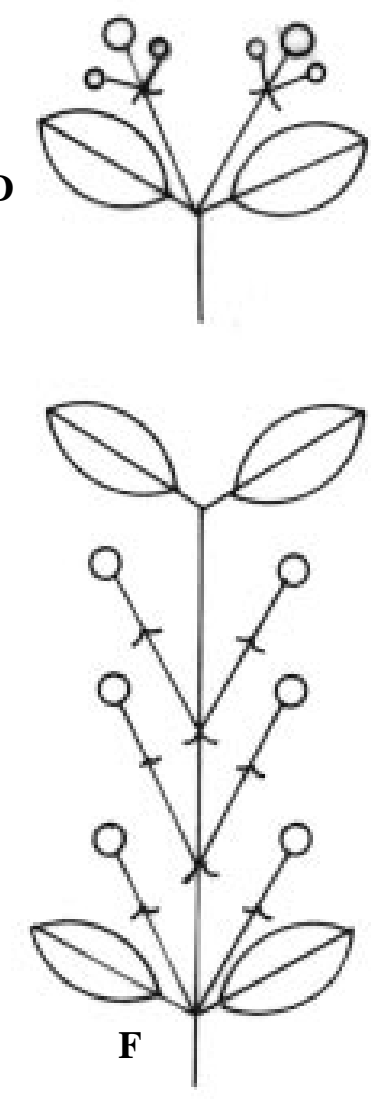

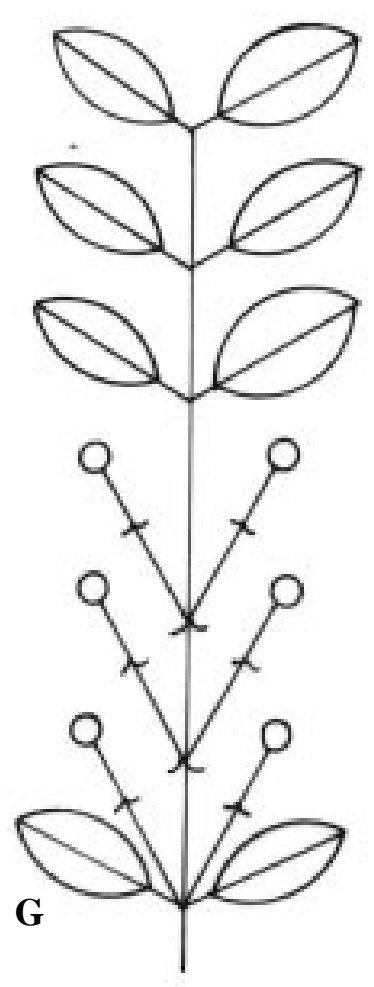

Figura 3. Desenho esquemático de inflorescências masculinas (A-D) e femininas (E-G) em Macropeplus. Tríades axilares em ramos folhosos (A), tríades axilares e extra-axilares (B), tríades em tirsos (C); tríades terminais (D); Monocásios axilares em ramos folhosos $(\mathbf{E})$, monocásios axilares e extra-axilares $(\mathbf{F}$ e $\mathbf{G})$. 


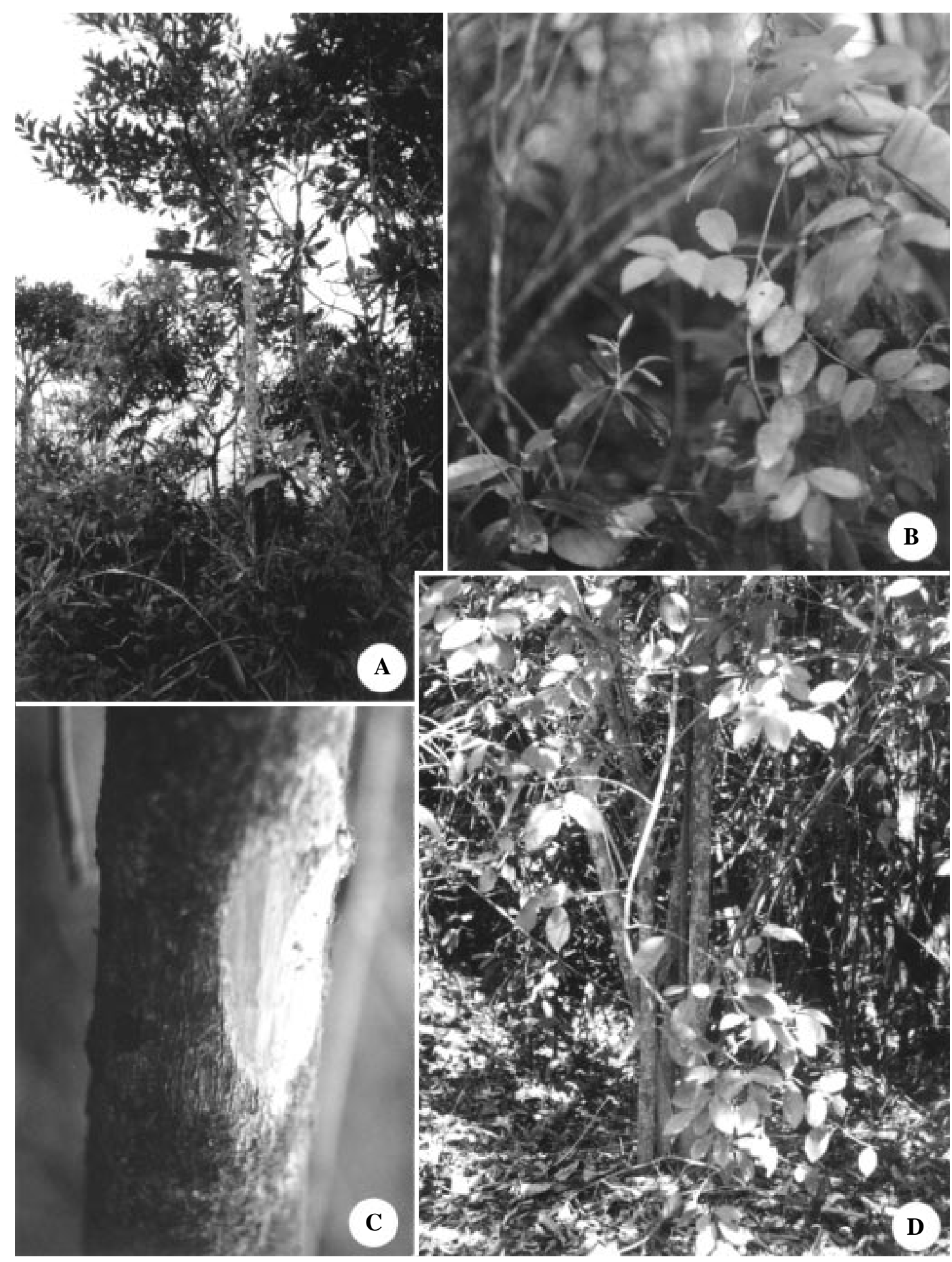

Figura 4. A. Macropeplus dentatus em transição da floresta alto-montana para o campo de altitude, Serra dos Órgãos, RJ (Santos et al. 63); B, C, D: Macropeplus ligustrinus: B. Exemplar arbustivo com ramos escandentes, em Grão Mogol, MG (Santos \& Germano Filho 26); C. Detalhe do ritidoma e da casca viva, em Brasília, DF (Santos \& Germano Filho 21); D. População densa (ao fundo) com exemplar perfilhado (em destaque) no interior de um capão de mata com solo argiloarenoso coberto por serrapilheira em Rio de Contas, BA (Santos et al. 22). 

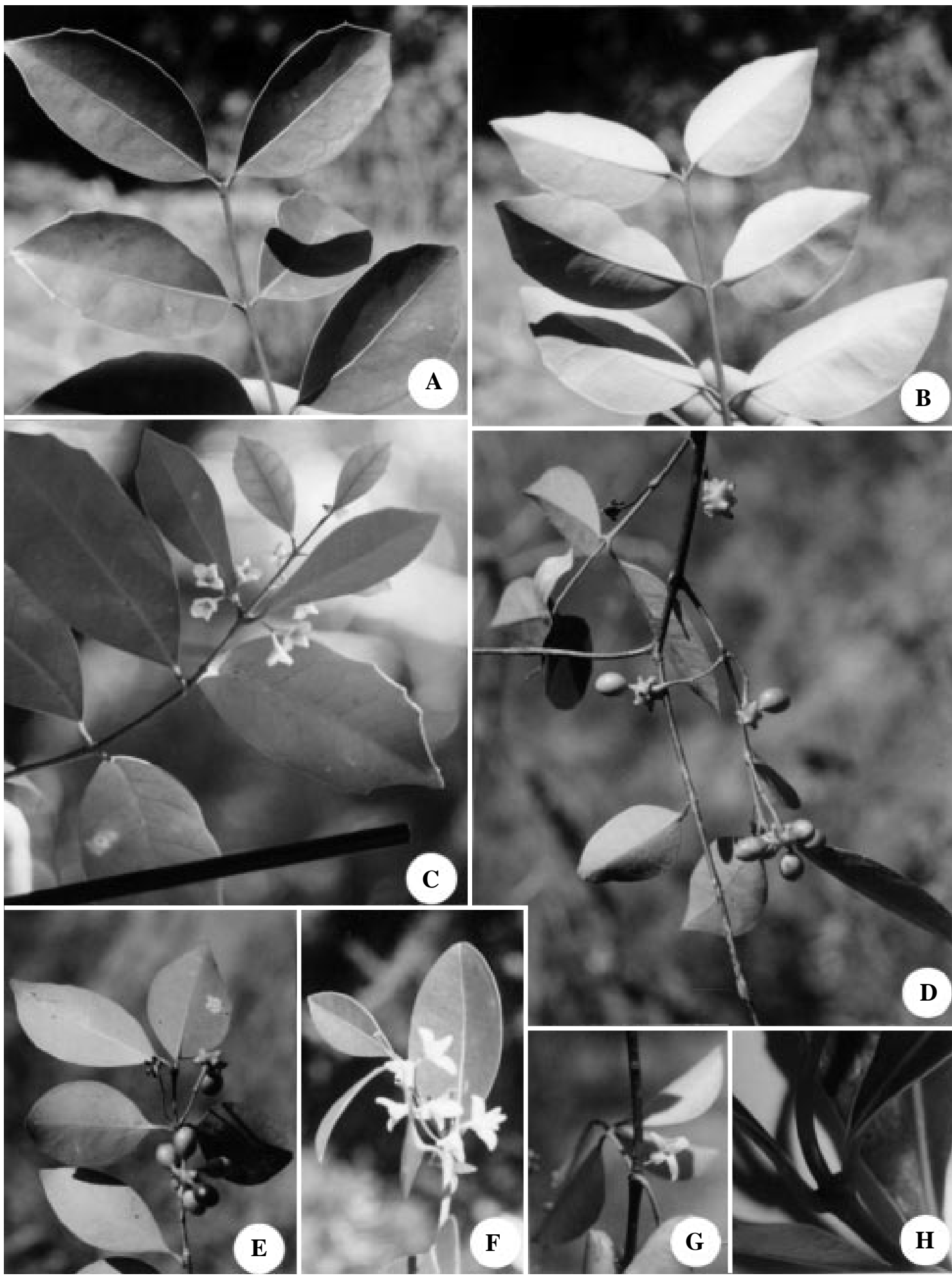

Figura 5. Fotografias de Macropeplus ligustrinus (A-G) e M. dentatus (H). A e B: Ramo vegetativo em vista ventral e dorsal (Santos et al. 64); C. Ramo florífero masculino (Santos et al. 64); D e E: Ramos frutíferos em diferentes estádios de maturação (Santos et al. 68); F: Ramo florífero masculino(Santos et al. 66); G: Ramo florífero feminino (Santos et al. 67). H: Detalhe dos pecíolos vináceos (Santos et al. 59). 
Em M. ligustrinus o pedúnculo comum da tríade é muito alongado, chegando a $3,2 \mathrm{~cm}$ de comprimento e os pedicelos $1,9 \mathrm{~cm}$ de comprimento, sendo as maiores inflorescências do gênero. $M$. friburgensis com pedúnculo comum até $1,4 \mathrm{~cm}$ de comprimento e pedicelo de até $0,9 \mathrm{~cm}$ de comprimento; $M$. dentatus com pedúnculo comum com até $1 \mathrm{~cm}$ de comprimento e pedicelo com $0,9 \mathrm{~cm}$ de comprimento e M. schwackeanus com pedúnculo comum até $1,2 \mathrm{~cm}$ de comprimento e pedicelo até $0,4 \mathrm{~cm}$ de comprimento, sendo a espécie que apresentam os pedicelos mais curtos.

FLORES: As flores de Macropeplus são actinomorfas, unissexuais, monoclamídeas, tetrâmeras, curta ou longamente pediceladas. São brancas em M. ligustrinus, $M$. friburgensis e $M$. schwackeanus e brancas a amarelo-esverdeadas em $M$. dentatus. $\mathrm{O}$ receptáculo é campanulado, como em $M$. schwackanus até curto e largamente campanulado como em M. ligustrinus. Externamente é glabro, e internamente, apenas nas flores femininas é densamente piloso.

Os lobos caliciniais são quatro, iguais dois a dois ou os exteriores pouco maiores do que os interiores, unidos parcialmente na base, imbricados, glabros, ápice agudo ou arredondado, margem membranácea. São oblongos a largamente lanceolados em $M$. ligustrinus, lanceolados em $M$. dentatus e $M$.

friburgensis. Os lobos mais internos apresentam-se cuculados, acomodando as anteras dos estames superiores, de modo geral maiores do que os inferiores (caráter bem evidente nas flores da população da Chapada Diamantina, no estado da Bahia).

$\mathrm{Na}$ antese, os lobos, nas flores masculinas tornam-se patentes (perpendiculares ao receptáculo) expondo as anteras, algumas localizadas muito próximas aos lobos, tornando-se exsertas. A abertura dos lobos nas flores femininas é menos evidente. Após a fecundação, nas flores femininas, os lobos e a parte superior do receptáculo rompem-se, de forma circuncisa, como caliptra, expondo os carpelos, comportamento comum aos gêneros de Mollinedieae neotropicais (Peixoto, 1987).

As flores masculinas apresentam 6-24 estames sésseis ou com filetes curtos, dispostos irregularmente no receptáculo, algumas vezes sendo possível visualizar-se 3-4 séries muito pouco definidas. As anteras, nos estames mais internos, são globosas e nos externos são alongadas e por vezes estéreis e petalóides, caráter também observado em espécies de Mollinedia (Peixoto, 1987). Este fato foi observado em M. dentatus (Fig. 10), M. ligustrinus e $M$. schwackeanus. A deiscência é rimosa, sendo os lóculos confluentes (anteras hipocrepiformes), ou não, então o conectivo é alongado. As flores femininas possuem 10-24 carpelos pilosos, com estilete curto, estigma verrucoso, incluso, secretor na antese; os óvulo são anátropos e pêndulos.

FRUTOS E SEMENTES: Fruto múltiplo com frutíolos (drupas) livres, ovóides ou elipsóides, sésseis ou curtamente estipitados, glabros ou esparsamente pilosos quando jovens, quando maduros são vináceos a nigrescentes (Figs. 5d,e). Endocarpo finamente crustáceo, castanho. Sementes com endosperma abundante, alvo, rico em óleo; testa castanha e embrião apical, muito pequeno. Receptáculo discóide, pouco desenvolvido na frutificação, amarelado a esverdeado. As drupas e o receptáculo frutífero nas quatro espécies de Macropeplus são muito semelhantes entre si e fornecem poucos recursos tanto para identificar as espécies como para separar estas daquelas dos outros gêneros de Mollinedieae neotropicais (Mollinedia e Macrotorus).

\section{DISTRIBUIÇÃO GEOGRÁFICA E ECOLOGIA}

Os táxons de Macropeplus ocorrem apenas em altitudes acima de $1.000 \mathrm{~m}$, estando distribuídos em cinco importantes maciços do Nordeste e Sudeste brasileiros e na Serra dos Pirineus e Distrito Federal, no Planalto Central (Figs 6 e 7).

A Serra do Espinhaço, a principal cadeia montanhosa à leste do Brasil, com altitudes 


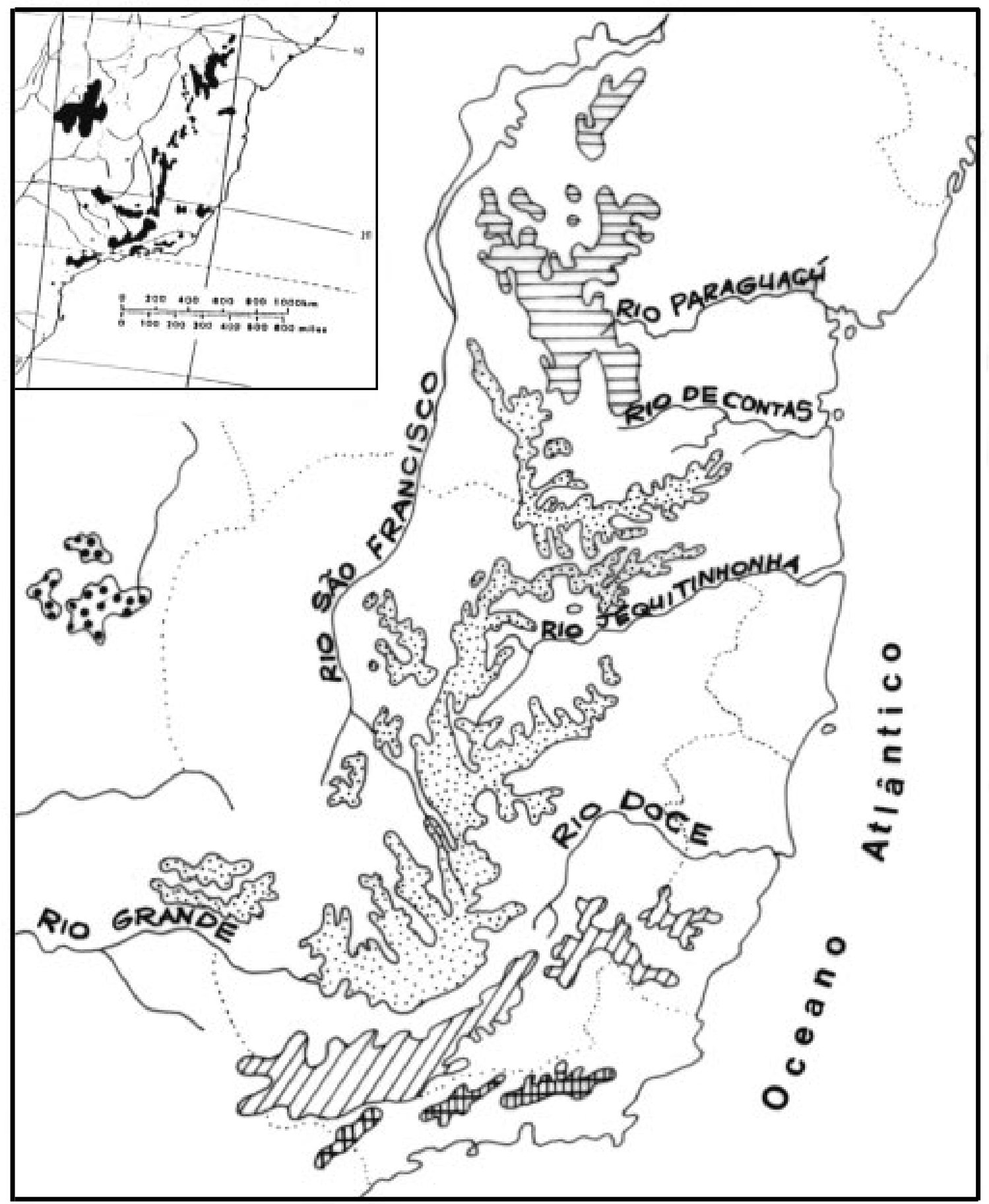

Figura 6. Cadeias montanhosas onde ocorrem as espécies de Macropeplus: 田 Serra do Mar;Z/ Serra da Mantiqueira; $\because$ Cadeia do Espinhaço; $\Xi$ Chapada Diamantina;:@: Região Central dos Cerrados 
entre 700 e 2.000 m.s.m, é constituída por dois blocos principais, a Chapada Diamantina, principalmente no estado da Bahia e a Cadeia do Espinhaço, em Minas Gerais (Giulietti \& Pirani, 1988; Harley, 1995). Entre a Chapada Diamantina e a cadeia do Espinhaço, ao norte de Minas Gerais, existem terras mais baixas, a cerca de 500 m.s.m., onde os solos são mais profundos. Essa área é cortada pelos vales do rio de Contas, rio Pardo e rio Jequitinhonha e representa atualmente uma barreira migratória parcial para a flora dos campos rupestres do norte para o sul e vice-versa (Harley, 1995).

Na Chapada Diamantina ocorre a espécie M. ligustrinus, que está representada por uma população bastante numerosa, sendo citada entre as espécies arbóreas mais freqüentes nas matas ripárias e capões na região do Pico das Almas, em altitudes entre 1.400 e 1.500 m.s.m. (Giulietti \& Pirani, 1995). A Cadeia do Espinhaço abriga duas espécies, $M$. schwackeanus em Itacolomi, na Serra de Ouro Preto e M. ligustrinus em Grão Mogol, Diamantina, Santana do Riacho e Santa Bárbara.

No Parque Nacional da Serra da Canastra, na Serra da Canastra, estado de Minas Gerais, ao sul da Cadeia do Espinhaço ocorre $M$. ligustrinus, aparentemente representada por uma população pequena e esparsa.

Dominam, nestas serras os campos rupestres com arbustos e árvores que crescem entre blocos de rochas em degradação, em solos de modo geral arenosos e pobres em matéria orgânica, mas com boa disponibilidade de água necessárias às exigências das espécies que aí habitam em populações esparsas (Giulietti et al. 1987, Pirani et al. 1994). As matas ripárias e capões ocorrem como ilhas florestais nos cerrados, caatingas e campo rupestres. O substrato no interior dos capões e das florestas ripárias contrasta com os campos adjacentes, por apresentar-se coberto por espessa camada de serrapilheira produzida pelas árvores (Meguro et al. 1996). A dinâmica de colonização e da expansão dos componentes lenhosos destes trechos de floresta é ainda muito pouco conhecida.

As espécies de matas ripárias e capões em áreas rochosas dos campos rupestres, de modo geral com menor índice de características xeromórficas, sofrem sérios danos com a ação de queimadas, sendo as espécies da orla das matas as mais atingidas. No município de Grão Mogol, na Cadeia do Espinhaço, habitat natural de M. ligustrinus observou-se que o local havia sofrido queimada no ano anterior e indivíduos de $M$. ligustrinus, como outras espécies da comunidade, tanto da orla como do interior da mata, encontravamse em processo de regeneração, especialmente por rebrotos. A espécie assim parece conseguir sobreviver a queimadas freqüentes na região. A população numerosa da Chapada Diamantina, na Bahia, habita vertentes mais úmidas e matas ripárias nos campos rupestres.

M. schwackeanus das Serras de Ouro Preto, também da Cadeia do Espinhaço, não foi observada em campo, embora esforço tenha sido feito neste sentido. Pelas características morfológicas observadas nos exemplares de herbário, como folhas pequenas e rígidocoriáceas, supõe-se que ela ocorra em ambientes mais extremos do que aqueles nos quais se pode observar as demais espécies.

A Serra da Mantiqueira está isolada da cadeia do Espinhaço por regiões mais baixas no Sul de Minas Gerais. Nela ocorre $M$. dentatus nos municípios de Campos do Jordão, São José dos Alpes, Cruzeiro e São Bento de Sapucaí, trecho reconhecido como Serra da Bocaina. Na Serra do Caparaó, trecho mais ao norte da Serra da Mantiqueira, em latitude próxima ao de Itacolomi, há uma coleta de $M$. schwackeanus (também não reencontrada). Em Campos do Jordão, na mata próxima ao estacionamento da Pedra do Bauzinho, $M$. dentatus ocorre no interior ou na orla da mata.

Apesar da Serra de Ibitipoca ser uma continuidade da Serra da Mantiqueira, a sua formação geológica e florística tem maior associação com a Cadeia do Espinhaço (Di Maio, 1996), ocorrendo aí M. ligustrinus. 
Na Serra do Mar ocorrem duas espécies: M. dentatus no Parque Nacional da Serra dos Órgãos, em Teresópolis (Pedra do Sino, 2.150) e M. friburgensis, na região de Macaé de Cima, em Nova Friburgo, na floresta altomontana, na transição para os campos de altitude ou mesmo em grotões nestes campos.

Os campos de altitude, iniciam-se acima de 1800 m s.m., nas Serras do Mar e da Mantiqueira. A vegetação dos campos de altitude é predominantemente arbustiva e herbácea e as espécies estão adaptadas a grande variação de temperatura entre o dia e a noite e a fortes ventos. É na floresta altomontana ou na transição desta floresta para os campos de altitude que habitam $M$. dentatus, na Serra dos Órgãos e Serra da Bocaina e $M$. friburgensis na área da Serra de Macaé de Cima, no município de Nova Friburgo e há uma coleta, de Brade número 9943, na Serra dos Órgãos na Pedra do Sino, no município de Teresópolis. Ao contrário das populações numerosas observadas em espécies do gênero ocorrentes nos cerrados e nos campos rupestres, $M$. dentatus e $M$. friburgensis, são de ocorrência rara, habitando o interior das matas entremeadas por campos rochosos.

Quando ocorre na margem de trilhas, exposta ao sol (tanto na Serra do Mar como na Serra da Mantiqueira), $M$. dentatus apresenta folhas menores e subcoriáceas, característica comum às espécies ecologicamente adaptadas a grandes altitudes, na Serra dos Órgãos.

A região central dos cerrados ocupa, predominantemente, maciços, planaltos de estruturas complexa, dotados de superfícies aplainadas de cimeira, além de um conjunto significativo de planaltos sedimentares compartimentados, situados a níveis de altitude que variam de 300 a $1700 \mathrm{~m}$. As formas de terrenos são, em sua maioria, similares tanto nas áreas de solos cristalinos, aplainados, quanto nas áreas sedimentares mais elevadas, transformadas em planalto típico. Freqüentemente, em algumas áreas, as florestas de galerias estendem-se continuamente pelo setor aluvial central de planícies deixando espaços para corredores herbáceos nos seus dois bordos, arranjo fitogeográfico reconhecido como veredas (Ab’Sáber, 1992-93).

Em contraste com a paisagem típica dos cerrados, a vegetação no fundo dos vales, entre as chapadas e ao longo dos rios que neles correm, é constituída por matas ripárias, com árvores bem desenvolvidas, crescendo sob solos orgânicos turfosos e ricos em nutrientes. Estas matas desempenham uma função importante como corredores de dispersão biológica, ligando o interior dos cerrados aos outros biomas circundantes, (Câmara, 199293). As matas ripárias também protegem as margens dos rios e riachos.

A altitude, aliada aos solos úmidos e ricos em nutrientes, favorecem a ocorrência de $M$. ligustrinus, que habita matas ripárias e capões em áreas da Estação Ecológica de Águas Emendadas, Parque Nacional de Brasília, Áreas de Proteção Ambiental Gama e Cabeça de Veado, Área de Proteção Ambiental São Bartolomeu, Fazenda Água Limpa, Jardim Botânico de Brasília e a Reserva Ecológica do IBGE.

\section{CONSIDERAÇÕES SOBRE ENDEMISMOS}

A região neotropical é a mais rica em espécies no mundo. Estima-se que cerca de 90.000 espécies de plantas superiores ocorrem no Neotrópico, o que representa cerca de $37 \%$ da flora mundial (Prance, 1999). Gentry (1986) afirma que a região Neotropical apresenta também um elevado grau de endemismo, citando que $25 \%$ das espécies vegetais existentes em Choco, no nordeste colombiano, são endêmicas. Guedes-Bruni et al. (1996) estimam que 50\% da flora vascular da Reserva Ecológica de Macaé de Cima, em Nova Friburgo, Rio de Janeiro, é constituída de plantas endêmicas da floresta atlântica, das quais Lima et al. (1997) apontam 7,8\% como restritas aos 7.000 ha da Reserva Ecológica de Macaé de Cima. 
É tratado como endemismo o padrão de distribuição em que um determinado táxon ocorre somente em uma região limitada. Dependendo da amplitude geográfica inferida, um táxon poderá ou não ser tido como endêmico (Di Maio, 1996), assim os padrões de endemismo serão diferentes em diferentes táxons, em diferentes regiões, em diferentes escalas. O estudo de endemismos em plantas tem importante papel na compreensão do desenvolvimento histórico da flora de uma determinada região (Stebbins \& Major, 1965), sendo então de grande interesse para os taxonomistas, entre outros motivos, por se relacionarem estreitamente com a história das floras locais.

As altitudes elevadas parecem ser condicionantes à existência de espécies de Macropeplus, gênero com espécies restritas a áreas com altitudes superiores a $1.000 \mathrm{~m}$, nas regiões Sudeste, Centro Oeste e Nordeste do Brasil. Pela distribuição geográfica do gênero e o reconhecimento de um conjunto de caracteres primitivos no grupo ao qual pertence (Monimiaceae, Monimioideae, Mollinedieae) Macropeplus pode ser considerado como paleoendêmico, de distribuição limitada a trechos das cadeias montanhosas nas serras da Chapada Diamantina, do Espinhaço, da Mantiqueira, do Mar e do Planalto Central. A família já estava presente e bem distribuída antes da separação dos continentes. As variações climáticas do pleistoceno provavelmente tenham influenciado na expansão e retração deste grupo de plantas pondo em contato e isolando populações de espécies. O desenho geológico e clima atual da terra propiciaram o confinamento das espécies a espaços relativamente definidos em altitudes elevadas. Macropeplus, assim, conjuga condições que caracterizam paleoendêmicos: é um grupo arcaico, com caracteres primitivos, que se apresenta com distribuição relictual devido as condições climáticas e geológicas atuais.

As altitudes elevadas implicam em diversos condicionantes ambientais. Quando separadas umas das outras, áreas de montanhas são comparáveis a ilhas, separadas entre si pelas condições ecológicas muito diferentes que existem nas áreas baixas, que atuam como barreiras para migração (Harley, 1995). No que concerne ao estudo da flora e das características adaptativas que possibilitaram o seu estabelecimento e sucesso ecológico, tais ilhas resultam num sistema propício a desenvolvimento de processos ecológicos e evolutivos que podem levar à especiação. Tratando de especiação em montanhas, Cain (1951) não vê problema em compará-las com a especiação ocorrida em ilhas marítimas em função do isolamento entre elas. Ele afirma que um tipo de distribuição comum é, dentro de um gênero, ocorrer uma espécie polimorfa de ampla distribuição acompanhada de algumas ou várias espécies endêmicas confinadas total ou quase totalmente a partes diferentes e relativamente pequenas de sua área. Cavalcante (1995), tratando especificamente de campos rupestres, diz serem frequientes os registros para gêneros com uma ou poucas espécies com distribuição geográfica ampla enquanto um número maior de espécies têm uma distribuição restrita. Neste padrão enquadra-se parcialmente o gênero Macropeplus no qual apenas uma de suas espécies, M. ligustrinus, tem distribuição mais ampla.

As espécies ocorrem em áreas restritas, com barreiras geográficas que naturalmente impedem a migração de espécies. O confinamento de populações com a conseqüente eliminação do fluxo gênico provavelmente levou ao surgimento de caracteres adaptativos particulares à cada população levando a endemismos em áreas restritas. Observou-se, tanto em campo como nos registros de plantas herborizadas, que as espécies são alopátricas, ou seja, crescem em espaços geográficos diferentes. Mesmo na Serra do Espinhaço e na Serra dos Órgãos onde há ocorrência de duas espécies, estas não foram observadas no mesmo trecho, ou com populações próximas entre si. 
As espécies de Macropeplus se enquadram no conceito de endemismo local (relictual ?), como tratado por Gentry (1986).

M. friburgensis tem a menor área de distribuição, estando restrito à floresta altomontana e transição para campos de altitude em Nova Friburgo e Teresópolis, na Serra dos Órgãos, Rio de Janeiro, sendo considerado endêmico local por Lima et al. (1997).

M. schwackeanus é conhecida também apenas de duas populações: o Pico do Itacolomi, na Serra de Ouro Preto, e o Pico das Macieiras, na Serra do Caparaó, sendo também, portanto, incluido no padrão de endemismo local.

M. dentatus ocorre na floresta altomontana e nos campos de altitude, sendo conhecido de uma população em Teresópolis, na Serra dos Órgãos, RJ e de populações mais extensas na Serra da Mantiqueira, em São Paulo, podendo ser considerado como endêmico regional.

M. ligustrinus tem a maior área de distribuição ocorrendo em matas ripárias e capões de mata nos campos rupestres na Cadeia do Espinhaço, Minas Gerais em várias populações (Grão Mogol, Diamantina, Santana do Riacho, Lima Duarte, Santa Bárbara, São Roque de Minas), na Chapada Diamantina (Rio de Contas e Lençóis) e no Brasil Central na Chapada da Contagem, no Distrito Federal e na Serra dos Pirineus, em Goiás.

\section{TRATAMENTO SISTEMÁTICO}

\section{A SUBFAMÍlIA MONIMIOIDEAE E A TRIBO MOLLINEDIEAE}

A subfamília Monimioideae está constituída por 26 gêneros, com representantes na região da Indonésia, Malásia, Austrália, Madagascar, Sul da África e na região Neotropical. No Brasil ocorrem quatro gêneros: Mollinedia, Hennercartia, Macropeplus e Macrotorus.

São árvores ou arbustos, monóicas ou dióicas com esclereídeos hipocrepiformes no caule. Folhas opostas ou ternadas. Flores unissexuais; reunidas em inflorescências pauci ou multifloras com receptáculo plano, campanulado ou cupuliforme e com lobos mais ou menos reduzidos em número e tamanho; anteras com deiscência rimosa, sendo a rima longitudinal ou transversal; com presença ou ausência de estaminódios. Pólen acolpado, óvulos pêndulos, anátropos.

Dos quatro gêneros de Monimioideae ocorrentes no Brasil, Hennecartia e Macrotorus são monotípicos. Hennecartia com distribuição subtropical, com ocorrência no Paraguai, Argentina, no Sul e no Sudeste do Brasil. Macrotorus é endêmico do Rio de Janeiro, na Serra do Mar e Macropeplus com distribuição em locais com altitudes elevadas, superiores a $1.000 \mathrm{~m}$, nas regiões Sudeste, Centro Oeste e Nordeste do Brasil com quatro espécies, reconhecidas neste trabalho. Mollinedia é o gênero com um maior número de representantes, cerca de 80 espécies, com ampla distribuição do Sul do México ao sul do Brasil.

A tribo Mollinedieae engloba dez gêneros, separados por Perkins \& Gilg (1901), em dois grupos. O que apresenta plantas dióicas, ocorrentes no Novo Mundo e no Brasil que são Mollinedia, Macropeplus e Macrotorus respectivamente e um segundo grupo que constitui-se de plantas monóicas com ocorrência na região Indo-Malaia (Mattea, Steganthera e Kibara), na Austrália (Tetrasynandra e Wilkia), em Madagascar (Ephippiandra) e em Nova Guiné (Anthobembix e Lauterbachia).

São árvores ou arbustos, dióicos de folhas simples, opostas, inteiras ou dentadas, glabras ou pubescentes. Tricomas simples. Flores pequenas, unissexuadas. As masculinas com receptáculo campanulado a urceolado, 4lobadas, com 8-60 estames, anteras com deiscência longitudinal ou transversal, coniventes ou não. As flores femininas apresentam receptáculo mais fechado que as masculinas, deiscência circuncisa em forma de caliptra; carpelos 6-130, uniovulados. Fruto apocárpico com drupas livres. 
Macropeplus difere significativamente dos demais gêneros da tribo, ocorrentes no Brasil, por apresentar o comprimento dos lobos maior do que o tamanho do receptáculo.

\section{DESCRIÇÃO DO GÊNERO MACROPEPLUS PERKINS}

Macropeplus Perkins, Bot. Jarhb. Syst. 25: 557. 1898; Pax, Pflanzenfam. Nachtr. 1: 26. 1891; Perkins \& Gilg, Pflanzenr. 4,101: 24. 1901; et in Engler, Pflanzenr. Nachtr. 49 (4.101): 12. 1911, pl.; Lemée, Dic. Descr. Syn. Gen. Pl. Phan. 4: 242.1932; Vattimo, Rodriguesia 32: 58. 1957; Hutchinson, Gen. Fl. Pl. 1:116. 1964; Giulietti, An. ICB, Un. Fed. Rur. Pernambuco 1(1): 99. 1971. Espécie Tipo: Macropeplus ligustrinus. Etimologia: Nome grego, originado da fusão de macro= longo $\mathrm{e}$ peplus=vestimenta, em referência ao comprimento dos lobos das flores.

Árvore ou arbusto, perfilhado ou não, dióico, com casca mais ou menos lisa, acinzentada, ramos estriados, cilíndricos, quando jovens vináceos; base dos ramos floríferos com ramentas. Folhas opostodecussadas, pecioladas; pecíolo canaliculado, freqüentemente vináceo; lâminas ovadas, ovado-lanceoladas, elípticas, elípticolanceoladas, oblongo-lanceoladas, lanceoladas a rombóideas, ápice acuminado, agudo a obtuso, base aguda, margem inteira ou dentada a partir do terço médio, levemente revoluta, glabras, discolores, cartáceas a rígido-coriáceas; nervação camptódroma, pouco proeminente na face adaxial e proeminente ou muito proeminente na face abaxial. Inflorescências axilares ou terminais em tirsos freqüentemente folhosos, as folhas de modo geral se desenvolvendo após a floração, pleiocásios (inflorescências parciais) em dicásios trifloros ou inflorescências reduzidas a dicásios trifloros ou monocásios, este último tipo apenas nos exemplares femininos; brácteas triangulares, agudas no ápice, pilosas no dorso, bactéolas lanceoladas, ambas caducas. Flores brancas, amareladas a esverdeadas, perfumadas, actinomorfas, receptáculo hipantóide cupuliforme a campanulado; lobos caliciniais ligeiramente desiguais entre si, dois a dois imbricados, freqüentemente dois maiores e dois menores, lanceolados a oblongos, glabros, com margem membranácea, ápice agudo. Flores masculinas com 6-26 estames, às vezes com 1-2 estaminódios (5 ocasionalmente em $M$. schwackeanus), dispostos no receptáculo sem séries definidas, os centrais geralmente sésseis e os externos com filetes curtos; anteras basifixas, bitecas, rimosas, confluentes ou não no ápice, as centrais sagitadas ou globosas e as externas alongadas, apresentando, às vezes, conectivo desenvolvido. Flores femininas com 6-24 carpelos livres, sésseis ou sub-sésseis, pilosos, estigma verrucoso, receptáculo internamente piloso. Perianto com deiscência circuncisa, em forma de calíptra, após a antese. Frutíolos drupas, globosas, vináceas a nigrescentes na maturação, epicarpo e mesocarpo levemente carnoso; semente pêndula, com testa castanha, preenchendo toda a cavidade do frutíolo, endosperma liso, alvo, embrião pequeno, reto, axial, contínuo, com cotilédones ovais.

Gênero endêmico do Brasil, com 4 espécies distribuídas nos estados da Bahia, Minas Gerais, Goiás, Distrito Federal, Rio de Janeiro e São Paulo.

Os gêneros Mollinedia, Macropeplus e Macrotorus (Monimioideae sensu Perkins \& Gilg, 1901, Mollinedioideae senso Philipson, 1980), ocorrentes no Brasil, têm um relacionamento estreito, compartilham diversos caracteres anatômicos e morfológicos, tanto vegetativos quanto reprodutivos, sendo de difícil separação. As flores apresentam 4 lobos, dispostos aos pares, imbricadamente. Em Macropeplus, alcançam o maior tamanho, excedendo sempre o comprimento do receptáculo (Peixoto, 1987).

O gênero Macrotorus diverge dos demais da tribo por possuir o receptáculo em forma de urna, muito maior do que os lobos, grande número de estames e anteras de forma variada, as basais hipocrepiformes, eretas e as laterais semi-circulares, as tecas horizontais; 
a deiscência das anteras se dá por meio de uma abertura única horizontal ou longitudinal (Peixoto et al. ined.b), enquanto nos demais gêneros da tribo, as anteras bitecas são longitudinais, com deiscência através de rimas verticais confluentes ou não no ápice.

Em Mollinedia o receptáculo e os lobos têm comprimento mais ou menos igual. As anteras, hipocrepiformes, podem ter os lóculos confluentes ou não no ápice. As flores femininas dos três gêneros brasileiros de Mollinedieae são muito semelhantes entre si, diferenciam-se principalmente pelo maior ou menor comprimento do receptáculo hipantóide. Os frutos são ainda mais semelhantes.

A estreita afinidade entre os gêneros leva, freqüentemente, a identificações errôneas das espécies pertencentes aos três gêneros, que são, de modo geral, identificados como Mollinedia, o gênero mais rico em espécies. Tal procedimento é reforçado pela escassa literatura sobre a família como um todo no Brasil, sendo a Flora Brasiliensis de Martius (1857) freqüentemente utilizada como fonte para identificação das espécies da tribo. Nesta obra, os três gêneros são tratados como Mollinedia.

\section{CHAVE PARA IDENTIFICAÇÃO DAS ESPÉCIES}

1. Folhas de margem sempre dentada; flores com lobos caliciniais maiores de (5) 6-7 (8) mm; Serra da Mantiqueira (RJ, SP) e Serra do Mar (RJ) 1. M. dentatus

1 '. Folhas de margem inteira ou com 1 a 5 dentes irregulares; flores com lobos caliciniais maiores de 3-5 (8-10) $\mathrm{mm}$.

2. Folhas rígido-coriáceas; nervuras muito proeminentes da face abaxial; flores com receptáculo cupuliforme; arbustos; Cadeia do Espinhaço (MG) e Serra do Caparaó (MG) 4. M. schwackeanus

2' Folhas cartáceas a subcoriáceas; nervuras proeminentes ou pouco proeminentes na face abaxial; flores com receptáculo campanulado; árvores ou arbustos

3. Estames 6-10 (-17); flores com os lobos caliciniais maiores de 4-5 (-8) mm; folhas, após desidratação, oliváceas; árvores; Serra do Mar (RJ) 2. M. friburgensis 3'.Estames (12-) 16-20 (-23-28); flores com os lobos caliciniais maiores de (4) 6-9 (10) mm; folhas, após desidratação, castanho-amareladas a castanho-oliváceas; árvores ou arbustos; Chapada Diamantina (BA), Cadeia do Espinhaço (MG), Serra da Mantiqueira (MG), Região Central dos Cerrados (GO, DF) 3. M. ligustrinus

\section{DESCRIÇÃO DAS ESPÉCIES}

1. Macropeplus dentatus (Perkins) I.Santos \& Peixoto, stat.nov. Tipo. Brasil. São Paulo: Serra da Bocaina, 9 set 1879 (fl mas), Glaziou 11551 (R! lectotipo; BR! C!). Etimologia: O epíteto específico faz referência à margem dentada das folhas.

Macropeplus ligustrinus (Tul.) Perkins var. dentata Perkins, Bot. Jahrb. Syst. 25: 560. 1898; Perkins \& Gilg, Pflanzenr. 4. 101: 26. 1901. Tipos. Brasil. Rio de Janeiro: Teresópolis, Serra dos Órgãos, próximo a Petrópolis, 19 nov
1889 (fl mas), Glaziou 17222 (C!); Serra dos Órgãos, 11 out 1869 (fl fem), Glaziou 4203 (BM! C!), Teresópolis, s.d., Moura s.n. São Paulo, Serra da Bocaina, 9 set 1879 (fl mas)(n.v.); Idem., 9 set 1879 (fl mas), Glaziou 11551 (BR! C!).

Fig. 7 e 9

Árvore 3-7 m de altura, copa densa, bastante ramificada. Folhas 3-6,5 $(8,5)$ x 0,85$1,5 \mathrm{~cm}$, lanceoladas, elíptico-lanceoladas a oblongo-lanceoladas, raro elípticas, ápice agudo a acuminado, raríssimo obtuso, base aguda, margem (2-) 5-6 dentes a partir do terço médio, cartáceas a subcoriáceas, face adaxial verde- 
escura, face abaxial verde mais claro; nervuras (7) 10-11 pares, levemente proeminentes na face abaxial e discretas na face adaxial, com ângulos de divergência de $30^{\circ}-69^{\circ}$; pecíolo $0,4-$ $0,6(0,9) \mathrm{cm}$. Pedúnculo 5-8 (10) $\mathrm{mm}$, pedicelo 5-8 (9) mm, brácteas 1-1,5 mm, ápice agudo a acuminado, bractéolas ca. $3 \mathrm{~mm}$, membranáceas, lanceoladas, ápice acuminado. Flores amarelo-esverdeadas a brancas, $5-8 \mathrm{~mm}$ de compr., receptáculo 1,5-2 x 2-2,5 mm, campanulado, lobos lanceolados, os menores (3 )5-6 (7) mm compr., os maiores (5) 6-7 (8) $\mathrm{mm}$, a larg. de ambos de 1-2 mm. Flores masculinas 11-17 (19) estames, os centrais fortemente apressos entre si, os mais externos às vezes 1-2 estaminoidais, então com conectivo prolongado acima das anteras. Flores femininas (11) 13-18 (19) carpelos pilosos com estigma verrucoso, dispostos no fundo do receptáculo. Drupas (6) 8-10 por infrutescência, arredondadas, 1-1,5 x 0,8-1,0 $\mathrm{cm}$, imaturas verdes, maduras vináceas, depois negras.

Distribuição e ecologia (Figs. 6 e 7). Espécie rara e endêmica, ocorrendo em populações relativamente esparsas nos estados do Rio de Janeiro e São Paulo, tanto na Serra da Mantiqueira quanto na Serra do Mar, em altitudes que variam entre 1.650 a 2.400 m.s.m., na floresta alto-montana e nos campos de altitude. Habita tanto o interior como a borda da floresta, crescendo preferentemente em solos rasos, negros, com alto teor de húmus. São conhecidas populações em Teresópolis, na Serra dos Órgãos e na Serra da Mantiqueira, no trecho que vai de São Bento de Sapucaí, Campos de Jordão, Cruzeiro, Bananal e Itatiaia. Das espécies de Macropeplus, M. dentatus e $M$. ligustrinus são as mais bem representadas em coleções de herbário e as menos sujeitas a pressões antrópicas por ocorrem em unidades de conservação, com áreas florestadas extensas e bem preservadas. $\mathrm{O}$ acesso às suas populações é também dificultado pela sua ocorrência em locais de difícil acesso e altitudes elevadas. Entretanto são áreas muito sujeitas a queimadas.
Considerando a dispersão da espécie em várias unidades de conservação embora representada por pequeno número de indivíduos nas populações, considera-se a espécie Vulnerável (UICN 1994). Foi coletada com flores de setembro a fevereiro e com frutos de março a junho.

Espécimes examinados: BRASIL. Rio de Janeiro: Teresópolis, próximo a Petrópolis, 19 nov 1889 (fl mas), Glaziou 17222 (C); Idem, Parque Nacional da Serra dos Órgãos, Pedra do Sino, 11 out 1869 (fl mas), Glaziou 4203 (BM, C); Idem, 08 nov 1929 (fl mas), Brade 9942 (R); Idem, 04 nov 1952 (fl mas), Vidal 5400 (R); Teresópolis, Pedra do Sino, vertente N, 24 dez 1952 (fl mas), Marcgraf 10456(RB, Z); Teresópolis, Campo das Antas, 05 set 1950 (fl), Barbosa, s.n (PNSO); Idem, 23 jan 1999 (fr), Santos et al. 60 (RBR); Idem, 23 jan 1999 (st), Santos et al. 63 (RBR); Idem, 23 jan 1999 (st), Santos et al. 62 (RBR);Teresópolis, Pedra do Chapadão, 15 out 1952 (fl mas), Marcgraf 10092 (RB, Z). Itatiaia, Pedra assentada, 14 fev 1935 (fl fem), Campos Porto 2788 (RB). São Paulo: Campos do Jordão, estrada para São José dos Alpes, 08 jun 1992 (fr), Gionotti et al. 26708 (UEC); Idem, 09 jan 1999 (st), Santos \& Germano Filho 56 (RBR); Idem, 28 mar 1994 (fr), Cordeiro et al. 1307 (SPF); Idem, 02 out 1985 (fl fem), Robim 321 (SPF); Campos do Jordão, região do Pinheiro-Seco, 01 out 1985 (fl mas), Robim 314 (SPF); Idem, 10 set 1937 (fl mas), Campos Porto 3383 (RB); Campos do Jordão, Parque Estadual Campos do Jordão, $22^{\circ} 43^{\prime} \mathrm{S}, 45^{\circ} 27^{\prime} \mathrm{W}$ ponto EFE-2, 27 abr 1981 (fr), Barreto 252 (RADAMBRASIL); Idem, 12 abr 1985 (fr im), Proença \& Bean, M.F. 504 (UB); Idem, out 1945 (fl), Leite s.n (FCAB 1970); Campos do Jordão, Horto Florestal, 06 out 1984 (fl mas), Sarti 22 (FCAB); Idem, out 1945 (fl mas), Leite s.n (FCAB). Cruzeiro, Alto Pico do Itaguaré, limite entre os estados de São Paulo e Minas Gerais, 2400 m, 04 jun 1995 (fr), Giulietti, et al. s.n (SPF 107154). São Bento do Sapucaí, estacionamento da Pedra do Baú e Bauzinho, 09 jan 1999 (st), Santos \& 


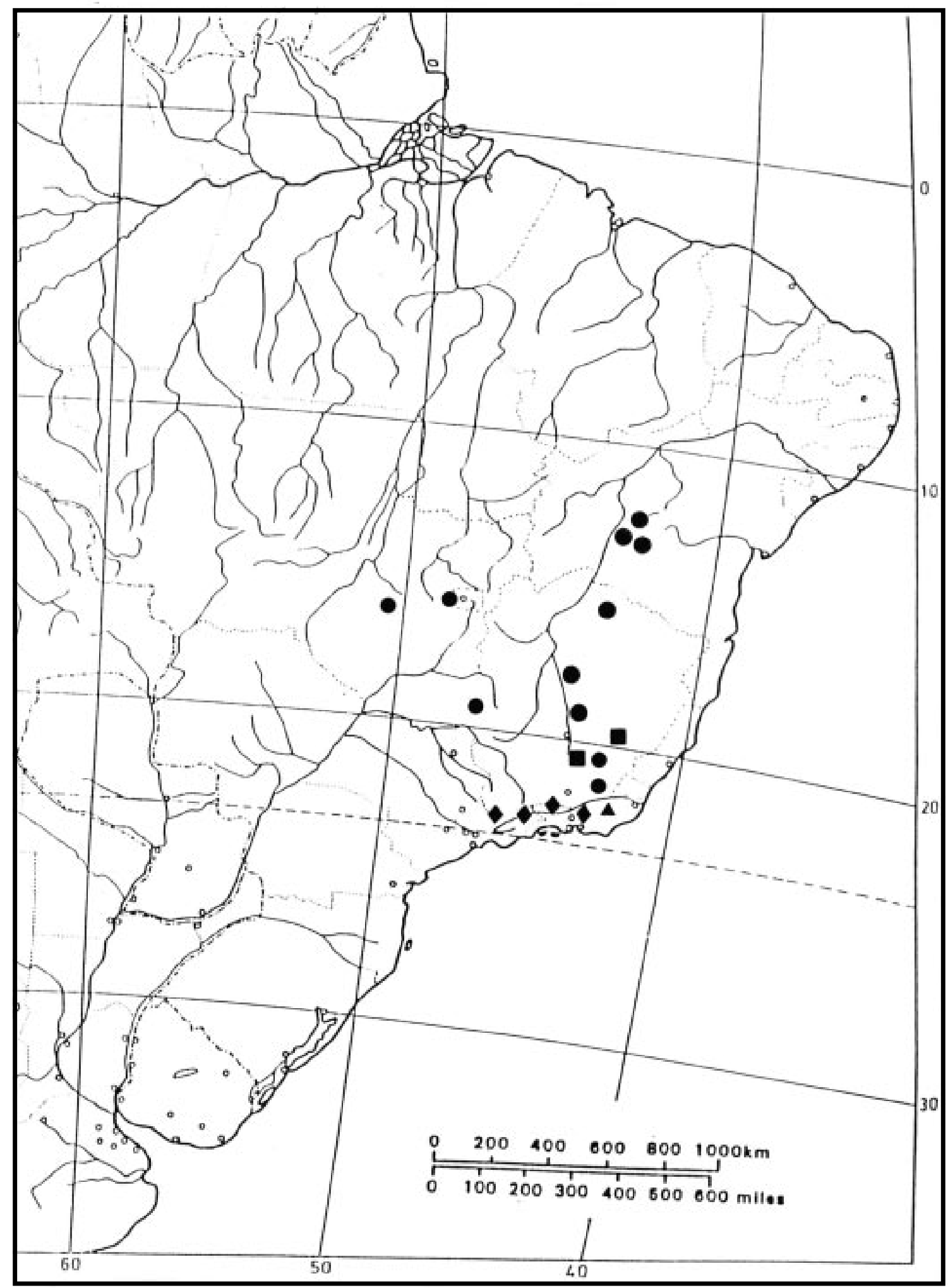

Figura 7. Mapa de ocorrência de: Macropeplus dentatus $(\bullet)$; M. friburgensis $(\boldsymbol{\Delta})$; M. ligustrinus ( • ); M. schwackeanus ( $)$ ). 


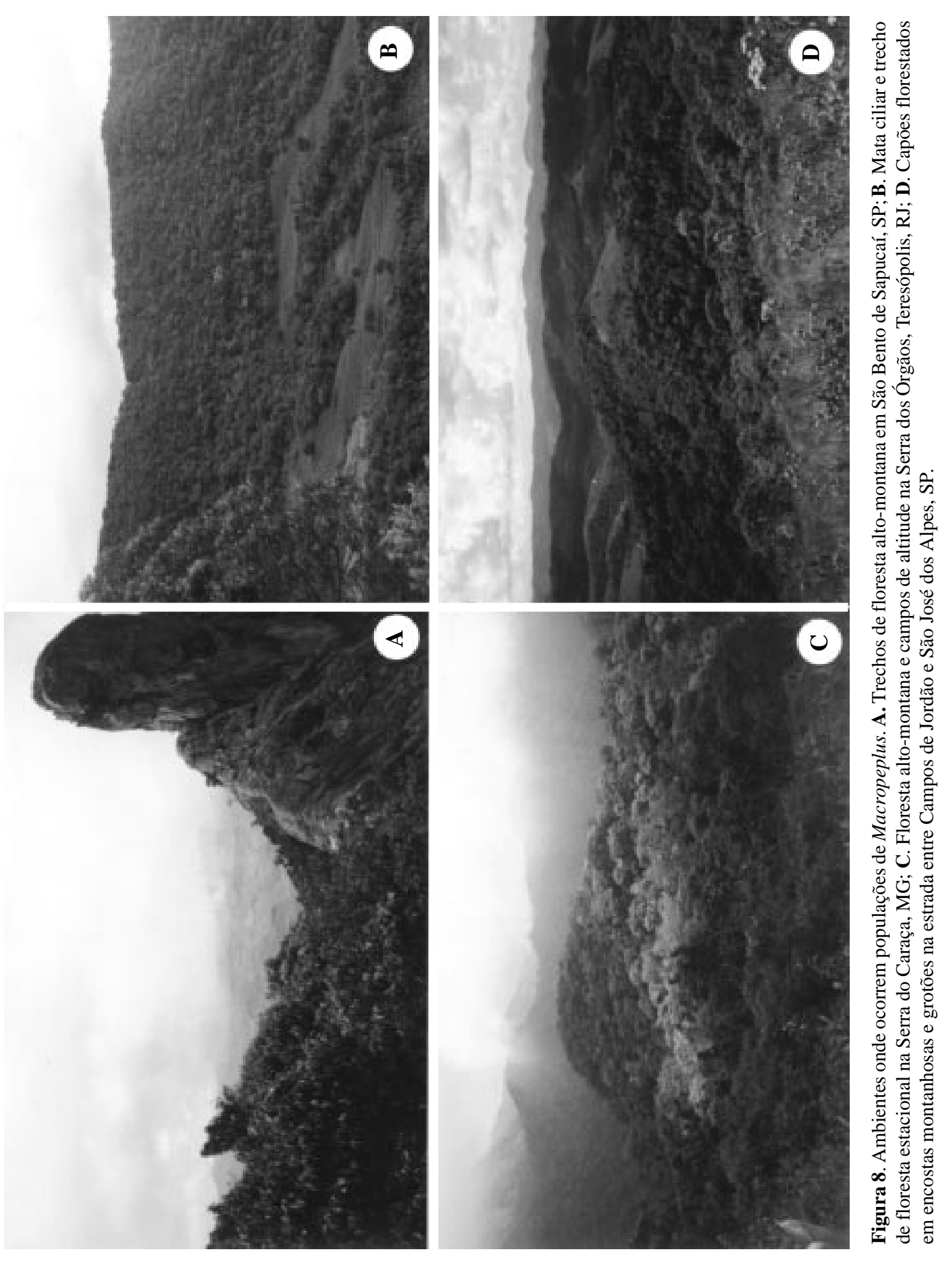




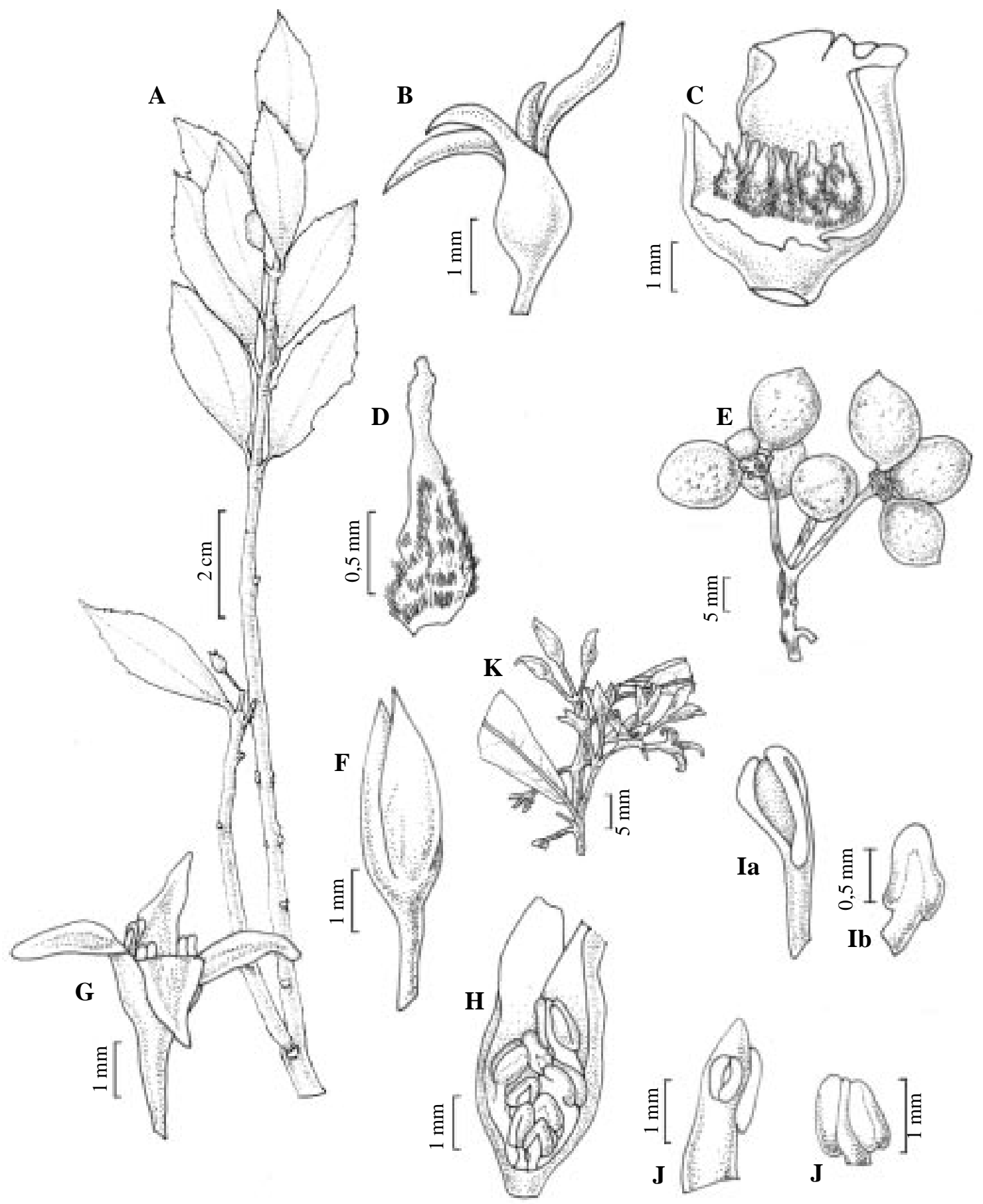

Figura 9. Macropeplus dentatus: A. ramo (Marcgraf 10092); B. flor feminina inteira e C. dissecada mostrando o receptáculo internamente piloso e os carpelos;D. carpelo (Robim 321); E. fruto múltiplo (Cordeiro et al.1307). F. botão floral masculino; G. flor masculina inteira e H. dissecada mostrando os estames; I. estames mais externos (a) e mais internos (b) ;J. estaminódio (Vidal 952); K. inflorescênia masculina (Robin, 314). 
Germano Filho 59 (RBR); Idem, 13 jun 1995 (fr im), Tamashiro et al. 867 (ESA, RBR); Idem, 09 jan 1999 (st), Santos \& Germano Filho 53 (RBR); São Bento do Sapucaí, margem da trilha para a Pedra do Bauzinho, 09 jan 1999 (fr im), Santos \& Germano Filho 54 (RBR). Serra do Bocaina, 09 set 1879 (fl mas), Schwacke 25 (R); Idem, 09 set 1879 (fl mas), Schwacke 1920 (R, RB).

É aqui proposta a mudança de status de Macropeplus ligustrinus var. dentata, descrita por Perkins em 1898, para espécie. Este táxon diferencia-se perfeitamente dos demais do gênero pelo hábito arbóreo (compartilhado com $M$. friburgensis), pelas folhas sempre dentadas, de dimensões 3$8,5 \times 0,85-2 \mathrm{~cm}$, que se tornam enegrescidas após o processo de desidratação ou a secagem natural (ramos secos).

Perkins quando descreveu a variedade dentata citou quatro síntipos: dois exemplares masculinos, um exemplar feminino e um (coleta feita por Moura s.n.) do qual não se pôde obter duplicatas para análise, e não se tem informação sobre a flor. Elegeu-se, no presente trabalho, o lectótipo para a espécie, exemplar Glaziou 11551, considerando-se a representatividade morfológica do espécime e a sua distribuição em coleções.

As coletas de Schwacke feitas na Serra da Bocaina, em São Paulo, em setembro de 1879 , representam a mesma espécie $M$. dentatus. Há dois exemplares no herbário $\mathrm{R}$, uma sem número de coleta (registo R 61045) e outra com o número 25 (registro R 23329), ambas datadas de 9 de setembro. Há fortes evidências de que a coleção Glaziou 11551, com duplicatas depositadas em BR, C e R sejam duplicatas destas coletas de Schwacke. Na duplicata desta coleção (Schwacke 1920), depositada no herbário $\mathrm{RB}$, que pertenceu ao herbário de Damásio, há a informação de que a coleta foi realizada por Glaziou e que recebeu o número 11551.
2. Macropeplus friburgensis (Perkins) I.Santos \& Peixoto, stat.nov. Tipo. Brasil. Rio de Janeiro: Nova Friburgo, Alto Macaé, Glaziou 20485 (K! Lectotipo; BR!). Etimologia: $\mathrm{O}$ epíteto específico faz referência ao local de coleta dos exemplares-tipos.

Fig. 7 e10

Macropeplus ligustrinus var. friburgensis Perkins, Bot. Jahrb.Syst. 25: 560. 1898. Perkins \& Gilg, In Engler, Pflanzenr. 4. 101: 26. 1901. Peixoto \& Pereira, Res. Ecol. Macaé de Cima, Nova Friburgo, RJ, 1: 303. 1996. Tipo. Brasil. Rio de Janeiro: Nova Friburgo, Alto Macaé s.d. (fl mas), Glaziou 17769 (C!).

Árvore de 4-15 m de altura, fuste de até $15 \mathrm{~cm}$ de diâmetro a altura do peito; ramos estriados. Folhas (6) 8-9 x $(1,5) 2-3 \mathrm{~cm}$, elípticas, oblongo-lanceoladas a rombóides, ápice agudo a acuminado, base aguda a cuneada, inteiras muito raro com 1-2 (3) dentes pouco distintos, levemente revolutas, opostas, raro subopostas, cartáceas, quando secas verde-olivas; nervuras (6-) 8-10 pares, ângulos de divergência de $28^{\circ}-60^{\circ}$, pouco evidentes na face adaxial e bem evidentes na face abaxial; pecíolo (0,6-) 0,8-1,8 cm compr. Pedúnculo (7) 8-14 mm, pedicelo $3-9 \mathrm{~mm}$, brácteas com ca. de $0,15 \mathrm{~mm}$ e bractéolas com $2-3 \mathrm{~mm}$ de compr. Flores esverdeadas a brancas, 6-8 (10) mm compr.; receptáculo 1,52,5 x 2-3 mm, lobos lanceolados com ápice agudo, os menores 3-4 (7) mm de compr., os maiores 4-5 (8) mm de compr., a largura de ambos de 1,5-2 mm. Flores masculinas 6-17 estames em 3-4 séries pouco definidas ou com distribuição irregular, os centrais sésseis e os mais externos com filetes curtos, aplanados e anteras mais alongadas; anteras confluentes no ápice; estaminódios, quando presentes, 21, triangular-alongados. Flores femininas 1018 carpelos pilosos, sésseis, estigma verrucoso, dispostos no fundo do receptáculo. Drupas até 7 por infrutescência, com ca de $1,7 \times 1,4 \mathrm{~cm}$. Receptáculo, na frutificação, 6-8 mm de diâmetro, com saliências de cerca de $2 \mathrm{~mm}$ onde se inserem os frutíolos; pedúnculo de 20$23 \mathrm{~mm}$. 


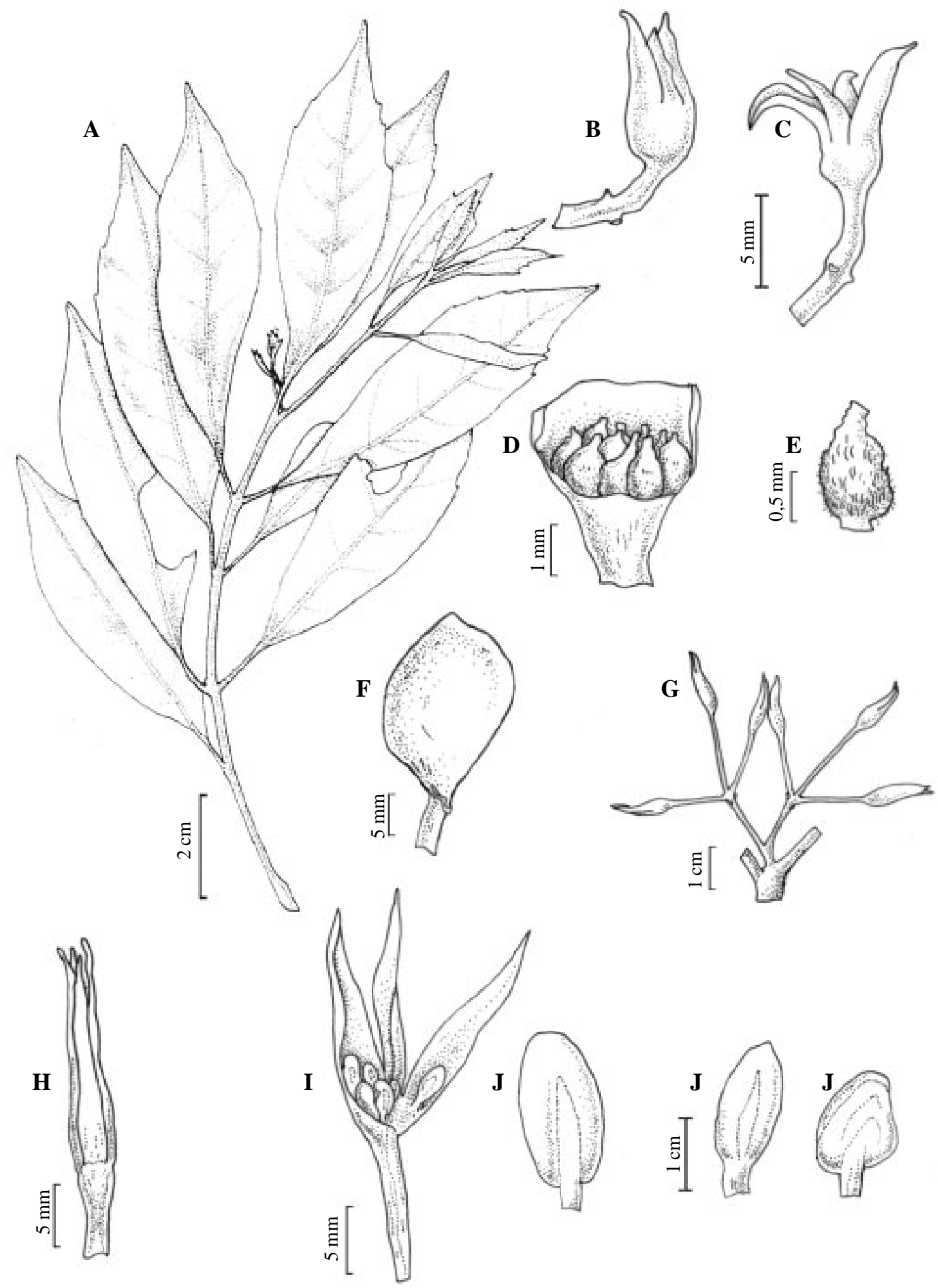

Figura 10. Macropeplus friburgensis. A. ramo (Lima et al 3456); B. flor feminina fechada, C. aberta e D. dissecada, após a deiscência dos lobos, mostrando o receptáculo internamente piloso e os carpelos; E. carpelo (Brade 9943); F. fruto (Pessoa et al. 504); G. inflorescência masculina; H. botão floral masculino; I. flor dissecada; J. estames (Lima et al 3456). 
Distribuição e ecologia: Macropeplus friburgensis é exclusiva da floresta altomontana e campos de altitude na Serra do Mar no estado do Rio de Janeiro, ocorrendo nos municípios de Nova Friburgo e Teresópolis em altitudes de 1.100 a 2.150 m.s.m. A distribuição dos espécimes é muito esparsa em suas populações. Peixoto \& Pereira-Moura (1996), comentam que até as duas últimas décadas a espécie era conhecida apenas pelos dois exemplares que a tipificam (coletas do século passado) e uma coleção do início do século (1929). Nas duas últimas décadas, várias coletas foram feitas, todas oriundas de uma população que ocorre na nascente do Rio das Flores, em Macaé de Cima, Nova Friburgo. Provavelmente a mesma população na qual Glaziou colecionou os exemplares tipos, no século passado.

A família Monimiaceae, na Reserva Ecológica de Macaé de Cima, Nova Friburgo, com 15 espécies, está citada entre as dez mais ricas, principalmente pelo grande numero de espécies de Mollinedia. Guedes-Bruni et al. (1996), em um trecho de 1 hectare e considerarando espécimes com DAP igual ou superior a $5 \mathrm{~cm}$, encontraram apenas um indivíduo de Macropeplus friburgensis. Devido a área de distribuição limitada e a baixa freqüência, a espécie é considerada em risco de extinção, na categoria Em Perigo (UICN, 1994). Foi coletada com flores nos meses de setembro e outubro e com frutos em julho.

Espécimes examinados: BRASIL. Rio de Janeiro: Nova Friburgo, Alto Macaé, Glaziou 17769 (C); Idem, 1894 (fl mas) Glaziou 20485 (BR, K); Idem, 09 dez 1918 (fl mas), Curran 640 (MO); Idem, Reserva Ecológica de Macaé de Cima, nascente do Rio das flores, $22^{0} 33^{\prime} \mathrm{S}, 42^{0} 42^{\prime} \mathrm{W}, 17$ out 1988 (fl mas), Lima et al. s.n, ind. 3199 (RB 294102, RBR), Idem, 17-21 out 1988 (st), Lima et al. s.n ind. 3198 (RB 294100, RBR); Idem, 19 out 1988 (fl mas), Lima et al. 3456 (RB, RBR); Idem, 1 set 1990 (fl mas) Silvestre et al. s.n. ind. 3198 (RB 294112); Idem, 1 jun 1990 (fr). Pessoa et al. 504 (RB);
Teresópolis, Pedra do Sino, 8 Nov 1929 (fl mas), Brade 9943 (R, RB).

Das espécies do gênero, M. friburgensis é a que alcança maior porte, atingindo até 15 $\mathrm{m}$, integrando então o estrato médio da floresta. Caracteriza-se pelas folhas cartáceas que adquirem, após o processo de desidratação, a tonalidade olivácea, raro acastanhada. A margem foliar é inteira, raramente 1-4-dentada, sendo os dentes irregulares e pouco evidentes o que a diferencia de $M$. dentatus, a espécie geograficamente mais próxima.

Os exemplares examinados apresentaram de 6-10 estames. Perkins (1898), entretanto encontrou 13-16 estames.

Macropeplus ligustrinus var. friburgensis foi descrita baseada em dois exemplares coletados por Glaziou. Neste trabalho propõe-se a mudança de status de Macropeplus ligustrinus var. friburgensis para espécie, bem como escolhe-se o lectótipo.

3. Macropeplus ligustrinus (Tul.) Perkins, Bot. Jahrb. Syst. 25: 558. 1898. Tipo. Crescit in Brasilia Meriodionali, Sellow 1122 (Lectotipo [Perkins, 1898] B).

Mollinedia ligustrina Tul., Ann. Sc. Nat. 4, 3: 44. 1855; Monogr. Arq. Mus. Hist. Nat. Paris 8: 393, t. 33. 1855; Fl. Bras. 4(1): 321, t. 86 1857; A.P. DC. In DC. Prodr. 16. 2: 668. 1868. Tipos. Brasil Meridional: s.l. (fl mas) Sellow 1037 (B); Idem, s.l. (fl mas) Sellow 1122 (B).

Macropeplus ligustrinus (Tul.) Perkins var. typica Perkins, Bot. Jahrb. Syst. 25: 560. 1898; Perkins \& Gilg, In Engler, Pflanzenr. 4. 101: 26. 1901. Tipo. Brasil Meridional: s.l. (fl mas) Sellow 1122 (B).

Macropeplus ligustrinus (Tul.) Perkins var. rhomboideae Perkins, Bot. Jahrb. Syst. 25: 559. 1898. Tipo. Brasil Meridional: s.l. Sellow 1037 (B).

Mollinedia pyrenea Taubert, Bot. Jahrb. Syst. 21: 427. 1896. Tipo. Brasil. Serra dos Pyrineus, ago (fl mas) Ule 3182 (B). Etimologia: O epíteto específico se refere ao local de coleta do exemplar tipo. 


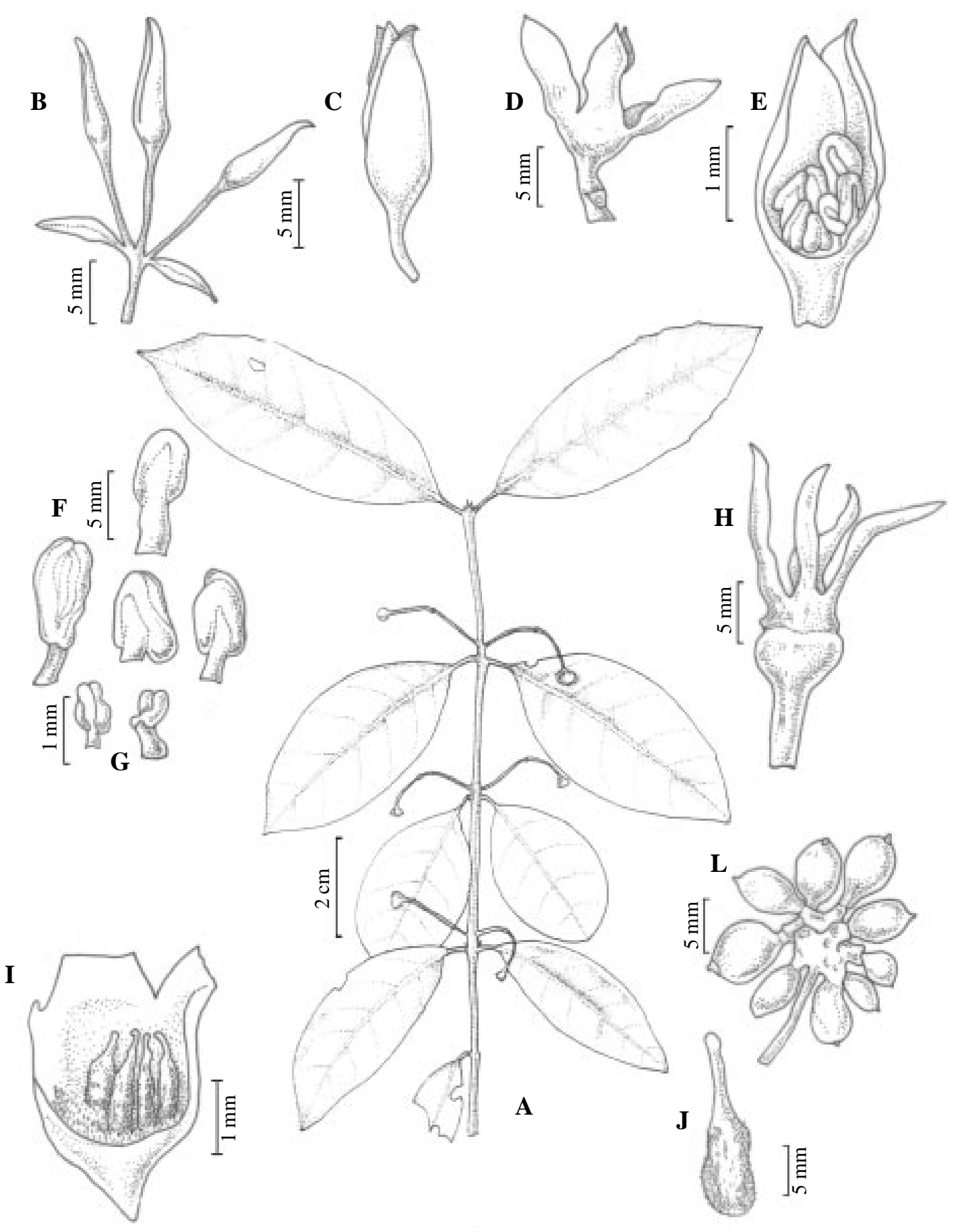

Figura 11. Macropeplus ligustrinus. A. ramo (Santos \& Germano Filho 28); B. inflorescência masculina; C. botão floral masculino;D. flor inteira e E. dissecada; F. estames (Harley et al. 25818); G. estaminódios; H. flor feminina em fase final da antese; I. flor feminina dissecada, após a deiscência dos lobos mostrando os carpelos; J. carpelo (Harley et al. 25112); L. Fruto múltiplo (Harley et al. 24531). 
Macropeplus ligustrinus (Tul.) Perkins var. pyrenea (Taubert), Perkins \& Gilg, Pflanzenr. 4 101: 26. 1901.

Macropeplus ligustrinus (Tul.) Perkins var. grandiflora Perkins, Bot. Jahrb. Syst. 25: 560. 1898. Tipo. Brasil. Goiás: cabeceiras do Rio das Pedras, Glaziou 22040 (BR! C! K! RB!). Macropeplus ligustrinus (Tul.) Perkins var. pohlii Perkins Perkins, Bot. Jahrb. Syst. 25: 560. 1898. Tipo: Brasil. Minas Gerais, Caraça, "bei Inficionada" Pohl 3561 (BR, fotografia do tipo BR!).

Figs. 7 e 11

Arvoretas ou arbustos, 1,5-7 $\mathrm{m}$ de altura, tronco 2-10 cm de diâmetro a altura do peito, freqüentemente com casca mais ou menos lisa, acinzentada, ramos longos, flexuosos, verdes, estriados, lenticelados. Folhas 4-9,5 $(12,5) \mathrm{x}$ 2,5-4,5 cm, ovadas, elípticas a oblongolanceoladas, ápice agudo a acuminado, base aguda, inteiras ou raro 1-3 (5) dentes discretos ou irregulares, levemente sub-revolutas, cartáceas a subcoriáceas, brilhantes, quando secas castanho-esverdeadas a castanhoamareladas; nervuras 8-11 pares, bem proeminentes na face abaxial, discretas na face adaxial, ângulo de divergência $\left(28^{\circ}\right) 47^{\circ}$ a $65^{\circ}\left(73^{\circ}\right)$, pecíolo $(0,3) 0,5-1 \mathrm{~cm}$, vináceo, canaliculado. Pedúnculo (7) $18-20 \mathrm{~mm}$, pedicelos $15-20 \mathrm{~mm}$; brácteas $1-15 \mathrm{~mm}$ compr., triangulares, pilosas no dorso, bractélolas 3-5 (7) $\mathrm{mm}$ lanceoladas. Flores brancas, muito perfumadas, 6-10 (15) mm compr., tubo curto, campanulado, 3-3,5 x 2-3 (5) $\mathrm{mm}$, lobos oblongos a largamente lanceolados, os maiores (4) 6-9 (10) $\mathrm{mm}$ e os menores (3) $5-8 \mathrm{~mm}$ compr., 2-3 mm larg., ápice agudo. Flores masculinas (12) 16-20 (23-28) estames, os centrais subsésseis, os externos com filetes curtos 1,5-2 mm compr. Flores femininas (15-) 17-20 (22-26) carpelos, sésseis, pilosos, estigma verrucoso. Drupas (6-) 11-16 (-22) por infrutescência, elipsóides, 1-1,5 x 7-9 cm, imaturas verdes passando a verde-amareladas, avermelhadas e por fim nigrescentes; receptáculo frutífero $0,5-0,6 \mathrm{~cm}$ larg., verde amarelado.
Distribuição e ecologia (Figs. 6 e 7). No Brasil leste ocorre no estado de Minas Gerais em Diamantina, Grão Mogol, Lima Duarte, Santa Bárbara, Santana do Riacho, São Roque de Minas. Na Bahia, ocorre nos municípios de Rio de Contas e Lençóis. No Brasil Central ocorre na Serras dos Pirineus, em Goiás e na Chapada da Contagem, no Distrito Federal. Suas populações habitam o sub-bosque de florestas ripárias e de florestas de grotões nos cerrados e campos rupestres. Ocorrem em altitudes que variam de 1000 a 1500 m.s.m., preferentemente em solos arenosos, com afloramento rochosos, ou áreas com grande quantidade de quartzítos, ou ainda cabeceiras de córregos, em locais mais úmidos, em solos areno-argilosos, com serrapilheira abundante.

Em Grão Mogol há uma população em área sujeita ao fogo, onde observou-se diversos indivíduos na orla da mata em rebrotos, como consequiência da queimada do ano anterior. As populações de Rio de Contas e Grão Mogol são numerosas, os indivíduos ocorrendo no subbosque e na orla de matas ricas em serrapilheira. São muitos os indivíduos jovens, com alturas inferiores a $50 \mathrm{~cm}$. Considera-se que a espécie não está em perigo de extinção. Foi coletada com flores nos meses de agosto a dezembro e com frutos em diversos meses do ano.

Espécimes examinados: BRASIL. Bahia: Rio de Contas, Pico das Almas, 21 fev 1987 (fr im), Harley et al. 24531 (UB,SPF, K); Idem, vertente leste, ao sudeste Vale do Queiroz, $13^{0} 32^{\prime} \mathrm{S}, 41^{\circ} 57^{\prime} \mathrm{W}, 21 \mathrm{dez} 1988$ (fr), Harley et al. 27318 (MO, UB, RB); Idem, 13 nov 1988 (fl fem), Harley et al. 26141 (RB, CEPEC); Idem, 31 out 1988 (fl mas), Harley et al. 25818 (UB, RB, CEPEC); Idem, $21 \mathrm{dez}$ 1988 (fr im), Harley et al. 27317 (CEPEC); Idem, 13 nov 1988 (fl mas), Harley et al. 26140 (CEPEC, RB); Idem, estrada entre o distrito de Mato Grosso e o pé do Morro Itabira, entre $13^{0} 24^{\prime} 30^{\prime \prime} \mathrm{S}, 41^{0} 51^{\prime} 13^{\prime \prime} \mathrm{W}$ e $13^{\circ} 22^{\prime} 50^{\prime \prime} \mathrm{S}$ 57'W s.d. (fr im), Sano s.n., CFCR 14708 (SPF); Idem, vertente leste, campo do Queiroz, perto da Fazenda Silvina, $13^{\circ} 32$ ' S, $41^{0} 57^{\prime} \mathrm{W}$ 
31 out 1988 (fl fem), Harley et al. 25816 (CEPEC); Idem, mata próximo à nascente do Rio Brumado, 29 out 1998 (fl mas), Santos et al. 64 (RBR); Idem, 29 out 1998 (fr), Santos et al. 65 (RBR); Idem, margem do Rio Brumado, 29 out 1998 (fl mas), Santos et al. 22 (RBR); Idem, 29 out 1998 (fl mas), Santos et al 66 (RBR); Idem, 29 out 1998 (fl fem), Santos et al. 67 (RBR); Idem, 29 out 1998 (fr), Santos et al. 68 (RBR); Lençóis: Serra da Chapadinha, 08 jul 1996 (fr) Giulietti s.n., PCD 3488 (CEPEC, UB). Minas Gerais: Diamantina, $3 \mathrm{~km}$ estrada Diamantina-Belo Horizonte para Conselheiro Mata 18 15'S 43 43'W, 30 out 1988 (fl fem), Harley et al.25112 (MO, SPF, RBR). Grão Mogol, montanha à esquerda do riacho Ribeirão, Trilha da Tropa, $42^{0} 55^{\prime} \mathrm{W}, 16^{0} 32^{\prime}, 03$ nov 1987 (fl ,fr), Cordeiro s.n. - CFCR 11429 (RBR); Idem, ca. $5-15 \mathrm{~km}$ ao norte da cidade, $16^{0} 32^{\prime} \mathrm{S}, 42^{\circ}$ 47'W 16 out 1988 (fl mas), Harley et al. 25108 (RBR); Idem, Trilha da Tropa, no alto da serra, 11 dez 1989 (fr), Pirani s.n. - CFCR 12446 (RBR); Idem, Serra do Barão, Trilha da Tropa, mata na margem esquerda da cabeceira do córrego da Tropa, à esquerda do rio Ribeirão, 01 nov 1998 (st), Santos \& Germano Filho 24 (RBR); Idem, 01 nov 1998 (st), Santos \& Germano Filho 25 (RBR); Idem, 01 nov 1998 (st), Santos \& Germano Filho 27 (RBR); Idem, 01 nov 1998 (fr), Santos 28 \& Germano Filho (RBR). Lima Duarte, Distrito de Conceição do Ibitipoca, Parque Estadual do Ibitipoca, sob a Ponte de Pedra, margem do rio, ca. 1280 m. 16 jan 1999 (st), Santos \& Germano Filho 51 (RBR); Parque Estadual do Ibitipoca, Trilha para o Lago do Espelho, ca 1350 m, 16 jan 1999 (st), Santos \& Germano Filho 43 (RBR). Santa Bárbara, Serra do Caraça, 18 nov 1977 (fl mas), Cruz et al. 6352 (RB); Idem, 12 dez 1978 (fl mas), Leitão Filho et al. 9539 (VIC); Santa Bárbara, Parque Natural do Caraça, trilha para gruta de N. Sra. de Lourdes, próximo a córrego, 19 dez 1998 (fr im), Santos \& Germano Filho 33 (RBR); Idem, 19 dez 1998 (fr im), Santos \& Germano Filho 34 (RBR); Idem, $19 \mathrm{dez}$
1998 (st), Santos \& Germano Filho 32 (RBR). Santana do Riacho, Serra do Cipó, estrada MG-10 cerca de $400 \mathrm{~m}$ antes da bifurcação entre o Morro do Pilar e Conceição do Mato Dentro, 23 set 1993 (fl mas), Campos \& Souza 13432 (SPF), Serra do Cipó, ca km $145 \mathrm{~N}$ de Belo Horizonte, 1200 m, margem de córrego, 14 fev 1968 (fr), Irwin et al. 20092 (UB). São Roque de Minas, Parque Nacional da Serra da Canastra 20 10'17'S 46 39' 52"'W, 13 dez 1997 (fr), Lombardi 1842 (BHCB). Goiás: Serra dos Pirineus, Ago 1892 (fl mas), Ule 747 (R); Cabeceira do Rio das Pedras, Glaziou 22040 (C, K, RB). Distrito Federal: Brasília, Fundação Zoobotânica, 30 abr 1963 (fr im), Pires et al. 9547 (UB); Idem, ca. 23 $\mathrm{km} \mathrm{S.W.} \mathrm{de} \mathrm{Brasília} \mathrm{na} \mathrm{rodovia} \mathrm{para} \mathrm{Anápolis,}$ 4 set 1964 (fl mas), Irwin \& Soderstrom 5966 (NY, UB, K, Z); Idem, ca. 15km E. de Brasília na rodovia para Paranoá, 22 set 1965 (fl mas), Irwin et al. 8556 (NY, RBR, Z,); Chapada da Contagem, ca. $20 \mathrm{~km} \mathrm{N.E.} \mathrm{de} \mathrm{Brasília,} 27$ out 1965 (fl mas), Irwin et al. 9610 (NY, R, RBR); Parque Nacional de Brasília, 05 set 1974 (fl mas), Heringer \& Herrenberg 13942 (NY, RBR, UB); Parque Nacional de Brasília, 21 nov 1984 (fl mas), França \& Proença 443 (UB, HEPH); Fazenda Água Limpa, próxima a Vargem Bonita, ca. $18 \mathrm{~km} \mathrm{SW}$ da antena de TV de Brasília, Córrego Olho d'água da Onça, 14 set 1976 (fl mas), Ratter et al. 3585 (MO, NY, UB); Idem, Córrego Capitinga, ca. 18 km SW da antena de TV de Brasília, 31 nov 1976 (fl mas), Ratter et al. 3907 (NY, UB, K); Reserva Ecológica do IBGE, 13 Set 1977 (fl mas), Heringer et al. 30 (IBGE); Idem, 10 ago 1978 (fl mas), Heringer et al. 585 (IBGE); APA do São Bartolomeu, Córrego Quinze próximo à nascente, 11 set 1985 (fl mas), Mendonça et al. 532 (IBGE, RB, UCE); Reserva Ecológica do IBGE, margem do Córrego Pitoco, $15^{0}$ 57' 46”' S, 470 52'44'W, 14 jun 1989 (fr), Pereira Neto \& Lopes 313 (RB); APA Gama e Cabeça de Veado, Córrego Taquara próximo confluência com Ribeirão do Gama, 29 ago 1990 (fr), Pereira 1421 (RBR); Idem, Reserva Genética, $15^{0} 52^{\prime} 0$ ” S, $47^{\circ}$ 
51'0" W, 09 abr 1996 (fr), Silva et al. equipe CENARGEN 175 (HEPH); Fazenda Água Limpa, margem do Córrego da Onça, $15^{0}$ 57'S, 470 55'S, 29 set 1994 (fl fem, fr), Walter 2245 (CEN, IBGE, R); Idem, Jardim Botânico de Brasília, 20 km de Brasília, Córrego Cabeça de Veado, 15 52', 470 51', 24 ago 1993 (fl mas), Ramos 557 (HEPH); Idem, Jardim Botânico de Brasília, margem de rio, no interior da mata, 27 out 1998 (st), Santos \& Germano Filho 20 (RBR); Idem, Jardim Botânico, margem de rio, interior da mata, 27 out 1998 (st), Santos \& Germano Filho 21 (RBR).

Macropeplus ligustrinus difere das demais espécies por apresentar os pedúnculos e pedicelos muito longos, podendo alcançar, respectivamente 12 e $35 \mathrm{~mm}$. As flores também são grandes, chegando a alcançar 11 mm de comprimento, o que levou Perkins (1898), a propor a variedade grandiflora, aludindo ao tamanho das flores. Posteriormente, Perkins \& Gilg (1901) colocaram a variedade grandiflora sob a variedade pyrenea, descrita anteriormente por Taubert (1896) como Mollinedia pyrenea. Apenas Macropeplus friburgensis tem flores de tamanho aproximado a esta espécie. O número de estames, 18-21, mais comum na espécie, foi ultrapassado por uma coleta, feita por Peixoto, no Parque Nacional de Brasília, com 25-26 estames. A espécie apresenta a maior variação no tamanho das folhas, desde pequenas, com $4,9 \mathrm{~cm}$ de comprimento e 2,2 $\mathrm{cm}$ de largura a muito grandes, com 11,5 cm de comprimento e $5,6 \mathrm{~cm}$ de largura. A variação no formato ocorre até no mesmo ramo, podendo variar de elípticas a elípticolanceoladas com ápices agudos e acuminados.

A coloração castanho-esverdeada a castanho-amarelada das folhas, após desidratação, a consistência e a venação são caracteres marcantes na espécie.

Giulietti (1971) embora não se refira a variedade, quando estudou as espécies de Monimiaceae do Distrito Federal, tratou claramente de M. ligustrinus var. pyrenae, considerada aqui como M. ligustrinus. Além da sua descrição morfológica coincidir com a desta espécie, o material ali citado pôde ser reexaminado. Mesmo reconhecendo a dificuldade de interpretação deste fato optouse por incluir a referência ao seu trabalho entre aqueles que trataram do gênero e não entre aqueles que trataram de M. ligustrinus var. pyrenae.

Tulasne (1855b) quando descreveu Mollinedia ligustrina indicou como tipos dois exemplares: Sellow 1037 e Sellow 1122, ambos procedentes do "Brasil Meridional". Posteriormente Tulasne (1857), na Flora Brasiliensis e Candolle (1868) deram o mesmo tratamento à espécie. Perkins (1898) cria o gênero Macropeplus, desmembra as coletas acima citadas e descreve, com base no exemplar Sellow 1037, a variedade rhomboideae, de Macropeplus ligustrinus, com folhas oblongas a oblongo-lanceoladas, cartáceas a coriáceas, flores masculinas com 13-14 estames. Estas características, exceto o número de estames, são compartilhadas com a variedade typica. Considerando que o número de estames é muito variável no gênero propõe-se que a variedade rhomboideae seja considerada sinônimo de M. ligustrinus (a variedade typica definida por Perkins).

4. Macropeplus schwackeanus (Perkins) I.Santos \& Peixoto stat. nov. Tipo. Minas Gerais: Ouro Preto, Itacolomy, (fl mas) Schwacke 7465 (RB! Lectotipo, BHCB!). Etimologia: O epíteto específico homenageia o botânico C.A.G. Schwacke, naturalista alemão, que viveu no Brasil de 1873 a 1904, quando exerceu o cargo de naturalista do Museu Nacional e professor de Botânica da Escola de Farmácia de Ouro Preto.

Macropeplus ligustrinus (Tul.) Perkins var. schwackeana Perkins, Bot. Jahrb. Syst. 25: 559. 1898.

Macropeplus ligustrinus (Tul.) Perkins var. xylophylla Perkins, Bot. Jahrb. Syst. 25559. 1898. Tipo. Brasil. Minas Gerais, Ouro Preto, Itacolomy, jul (fl mas) Glaziou 18482 (C! K!). Figs. 7 e 12 


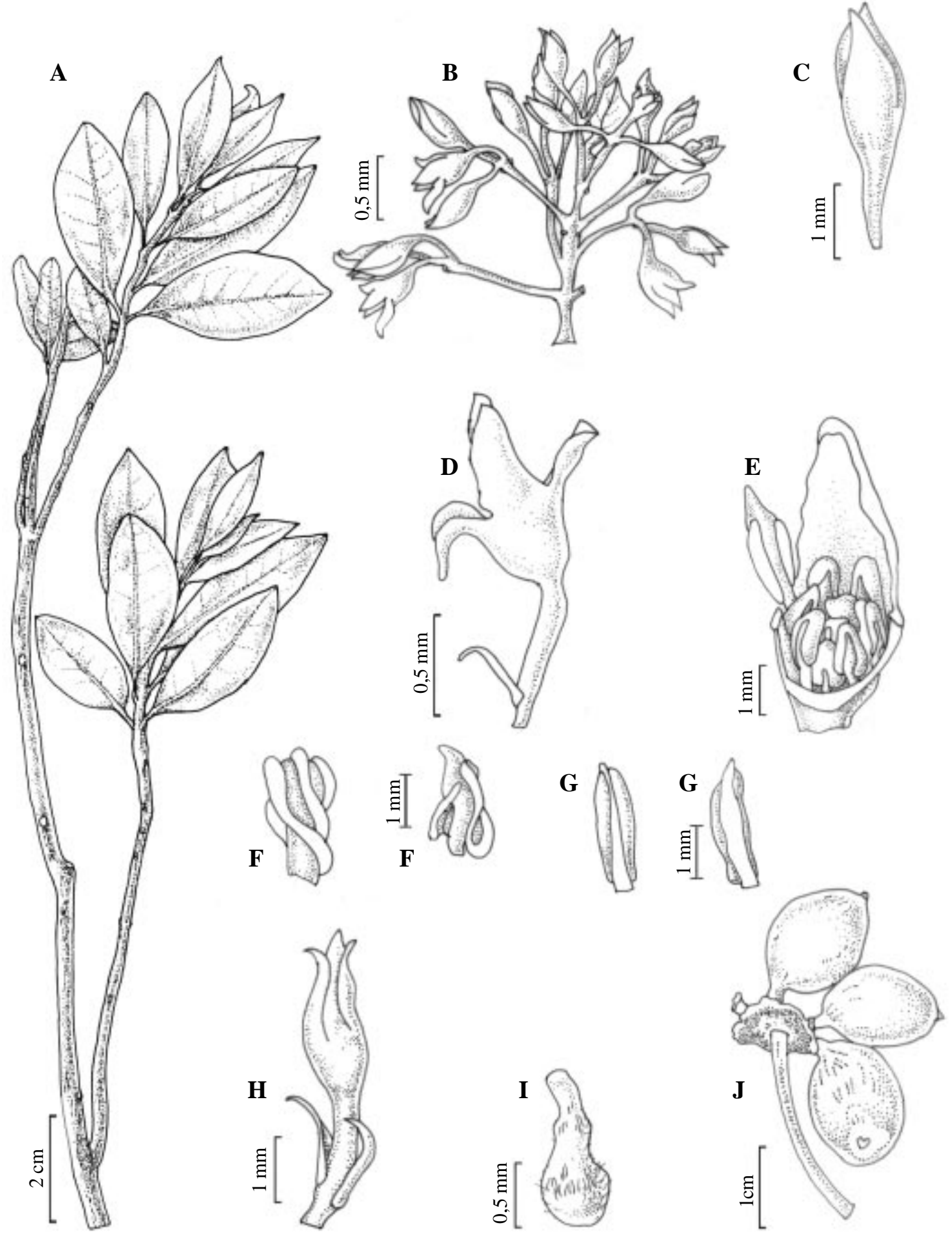

Figura 12. Macropeplus schwackeanus. A. ramo (Atala 328); B. inflorescência masculina; C. botão floral masculino (Schwacke s.n RB 42506);D. flor inteira e E. dissecada; F. estames (Cardoso s.n. BHCB 3670); G. estaminódios; H. flor feminina; I. carpelo (Schwacke 12353); J. fruto múltiplo (Schwacke s.n. RB 42551). 
Arbusto, muito ramificado. Folhas 2,5-5 x 1,0-2,5 cm, ovadas a elípticas, ápice agudo a obtuso, base aguda, inteiras, raríssimo 1-3dentadas, revolutas, rígido-coriáceas; nervuras (7) 8-9 (11) pares, mais salientes na face abaxial e proeminentes na face adaxial, ângulos de divergência com a nervura principal $40^{\circ}-50^{\circ}$, pecíolo $0,3-0,4(0,5) \mathrm{cm}$ compr. Dicásios trifloros, raro tirsos, pedúnculo 6-8 (9) $\mathrm{mm}$, pedicelo $2-4 \mathrm{~mm}$, brácteas $2,5 \mathrm{~mm}$ compr., triangulares, bractéolas 2,5 $\mathrm{mm}$ compr, lanceoladas. Flores brancas, botões 4-6 mm compr., receptáculo cupuliforme, 1-2 mm x 1,52,5 mm, lobos menores 2-4 mm de compr., os maiores 3-5 mm. Flores masculinas (8-) 17-19 estames, os centrais subsésseis, com anteras menores e os mais externos com anteras maiores, após a antese torcidas, estaminódios (até 5) às vezes presentes. Flores femininas com pedúnculo de $3-4 \mathrm{~mm}$, pedicelo de $2-3 \mathrm{~mm}$, bractéolas de $2-3 \mathrm{~mm}$, bráctea ca $1 \mathrm{~mm}$. Frutos 0,7-0,9x0,55-0,7cm, estipitados; pedúnculo da infrutescência ca de $1 \mathrm{~cm}$, pedicelo ca $1,2 \mathrm{~cm}$, receptáculo frutífero ca $0,6 \mathrm{~cm}$.

Distribuição e ecologia (Figs. 6 e 7): $M$. schwackeanus é conhecida apenas para o estado de Minas Gerais, onde ocorre no Pico do Itacolomi, em Ouro Preto e de Macieiras, na Serra do Caparaó. Habita matas de grotões nos campos rupestres, preferentemente em solos úmidos, em altitudes em torno de 1.797m.s.m. Embora tenha-se tentado localizar populações desta espécie no campo, não se obteve ainda êxito nesta busca. Com base nas poucas coleções depositadas em herbários, na aparente distribuição restrita e na dificuldade de localizar exemplares no campo, considerase $M$. schwackeanus uma espécie rara e Insuficientemente Conhecida (UICN, 1994). A espécie foi coletada em flores nos meses de julho e novembro.

Espécimes examinados: Brasil. Minas Gerais: Serra do Caparaó, 14 nov 1960 (fl mas), Atala 328 (GUA, RB); Ouro Preto, Itacolomi, 22 out 1903 (fl mas), Cardoso s.n (BHCB 3670); ibid., Schwacke 7465 (RB, BHCB); Ibid., Ouro Preto, Glaziou 18482 (C,
K); Ibid., fev 1892, Ule 2441 (R); Serra de Ouro Preto, fev 1894 (fl fem), Schwacke s.n. (RB 42511); s.l., s.d., (fl fem), Schwacke 9404 (RB); s.l., s.d., (fr), Schwacke 10.388 (RB); s.l., s.d., (fl fem), Schwacke 12353 (RB); s.l., s.d., (fl mas), Schwacke s.n. (RB 42506).

Macropeplus schwackeanus caracteriza-se pelas folhas rígido-coriáceas, com margem inteira, raro 1-3 dentada, subrevolutas, nervuras na face abaxial fortemente proeminentes. Baseando-se nas coletas de Glaziou 18482 e Ule 2441, procedentes de Itacolomi, Ouro Preto, Perkins (1898) descreveu a variedade xylophylla, caracterizada por apresentar folhas inteiras ou 1-2 dentadas, rígido-coriáceas, com nervuras proeminentes na face adaxial, inflorescências sempre em dicásios simples e flores com 1011 estames. Diferenciou esta variedade da variedade schwackeana principalmente por esta apresentar 19 estames e as inflorescências paniculadas raro em dicásios simples.

Após a análise do material que se teve em mãos, inclusive exemplares tipos, constatou-se que tais características não sustentavam os dois táxons separadamente e optou-se por incluir a variedade xylophylla sob M. schwackeanus, agora elevada à espécie. Além da semelhança no tamanho e forma das flores, nas folhas rígido-coriáceas e pequenas (3,1-4,9 x 1,0-2,1) as espécies partilham do mesmo habitat, integrando a flora de grotões úmidos nos campo rupestres.

\section{CONCLUSÕES}

$\mathrm{O}$ estudo taxonômico de Macropeplus levou ao reconhecimento de quatro espécies no gênero, resultado da elevação de status de quatro variedades. Macropeplus dentatus (Perkins) I.Santos \& Peixoto, M. friburgensis (Perkins) I.Santos \& Peixoto, M. ligustrinus (Tul.) Perkins e M. schwackeanus (Perkins) I.Santos \& Peixoto. As espécies são distintas predominantemente com base na margem e consistência das folhas, bem como na coloração que as folhas adquirem quando secas, tanto em campo quanto em laboratório; 
distinguem-se também pelo comprimento dos lobos caliciniais, número de estames e o comprimento do pedúnculo e do pedicelo. As descrições da espécie e das variedades de Macropeplus foram feitas no final do século XIX. Provavelmente uma das grandes dificuldades do autor das variedades, na época, foi ter lidado com um pequeno número de exemplares e o não acesso a exemplares vivos, no campo. Em decorrência desse fato, e a dificuldade de se encontrar caracteres marcantes e consistentes para separar os táxons, levou Perkins à criação de um número considerável de variedades. Ainda hoje há pouco exemplares do gênero depositados em herbários nacionais e do exterior. Isto se deve, em grande parte, aos locais de ocorrência das espécies, de modo geral de difícil acesso. A espécie melhor representada em herbários é M. ligustrinus, de distribuição mais ampla e que habita alguns locais de mais fácil acesso. Também, por ocasião das expedições de campo para elaboração da Flora Fanerogâmica do Estado de São Paulo, Macropeplus dentatus aumentou significativamente a sua representação em herbários. As demais espécies habitam locais pouco explorados pelos coletores botânicos.

Quatro variedades foram sinonimizadas: a variedade xylophylla foi sinomimizada sob M. schwackeanus e as variedade rhomboideae, pholii e pyrenae (e typica) sob M. ligustrinus.

Durante o estudo foram localizadas nove populações no campo: cinco de $M$. ligustrinus, uma de $M$. friburgensis e três de $M$. dentatus. Não se pode localizar ainda nenhuma população de M. schwackeanus.

As espécies do gênero estão restritas a altitudes superiores a $1.000 \mathrm{~m}$. Habitam a floresta pluvial alto-montana, campos de altitude, campos rupestres e florestas ripárias ou capões úmidos nos cerrados, em cinco importantes maciços: Chapada Diamantina, Cadeia do Espinhaço, Serra da Mantiqueira, Serra do Mar e serranias no Planalto Central.

As espécies de Macropeplus apresentam endemismos local ( $M$. friburgensis e $M$. schwakeanus) e regional (M. dentatus). M. ligustrinus é a espécie de maior área de distribuição, ocorrendo na Bahia, Minas Gerais, Goiás e Distrito Federal. Ocupam exclusivamente áreas de vegetação natural e com pouca interferência antrópica..

M. friburgensis é exclusiva da Serra do Mar, no Rio de Janeiro, ocorrendo nos municípios de Nova Friburgo e Teresópolis; $M$. schwackeanus é endêmica de Minas Gerais, ocorrendo na Serra de Ouro Preto e Serra do Caparaó; M. dentatus ocorre na Serra do Mar e na Serra da Mantiqueira, no Rio Janeiro e São Paulo.

M. ligustrinus e $M$. dentatus são as espécies mais sujeitas a impactos ambientais: na Serra do Caraça, na Serra de Ibitipoca, na Serra do Cipó, na Serra dos Órgãos, em Campos do Jordão, em São Bento do Sapucaí e São José dos Alpes, pode-se observar espécimes danificados por ação do fogo ou pela abertura de picadas ou estradas. De modo geral os espécimes danificados reagiram ao impacto do corte ou da queimada, com rebroto.

Embora as populações das espécies sejam de modo geral pequenas, o que pode colocar em risco a sobrevivência do grupo ou inviabilizar geneticamente a sua sobrevivência, todas as espécies têm populações resguardadas em unidades de conservação. $M$. ligustrinus foi considerada não ameaçada; $M$. friburgensis e $M$. dentatus foram consideradas Em Perigo; M. schwackeanus, espécie rara e insuficientemente conhecida, foi considerada com Dados Incompletos, necessitando de forte investimento na busca de populações no campo para uma avaliação segura do seu grau de ameaça.

\section{AGRADECIMENTOS}

A Pedro Germano Filho pelo companheirismo e auxílio nas expedições de campo, na elaboração das ilustrações e na diagramação do texto; à coordenação do curso de Pós-Graduação em Botânica pelo apoio recebido; aos professores e funcionários do 
Departamento de Botânica da UFRRJ pelo incentivo e apoio; aos curadores dos herbários nacionais e estrangeiros visitados ou que cederam, por empréstimo ou doação, exsicatas e fotografias de exsicatas; aos diretores, responsáveis ou funcionários das Unidades de Conservação visitadas do IBAMA (DF e MG), Instituto Estadual de Florestas de Minas Gerais e Instituto Florestal de São Paulo, entre os quais se destacam o Sr. Albino, do Parque Nacional da Serra do Cipó; Srs. Paulo Roberto e Bráulio do Parque Estadual do Ibitipoca, Sr. Alberto do Parque Estadual do Itacolomi; Pe. Célio Maria de lla Amore, do Parque Natural do Caraça; Ao Sr. Manuel Fernando R. Pinto e Dr. A. L. Toscano de Brito, de Rio de ContasBA, Sr. Geraldo R. Fróis, Sra. Carolina Luíza, de Grão Mogol-MG, Prof. Antonio X. dos Santos, da Fazenda Água Limpa (DF), Sr. Edson e Sra. Gorete, do Jardim Botânico de Brasília, Paulo Ormino e Robério (Rio de Contas, BA), Edmar Marques (Serra do Cipó, MG), César Sampaio (Serra dos Órgãos, RJ), Francisco Paulo (Jardim Botânico de Brasília, DF) e Lucélia Vitória (Conceição do Ibitipoca, MG) pela companhia na busca de espécimes de Macropeplus.

\section{REFERÊNCIAS BIBLIOGRÁFICAS}

Ab'Saber, A.N. 1992-93. No domínio dos cerrados. In Cerrado, vastos espaços. Edições Alumbramento/ Livroarte Edit. 29-34 p.

Barroso, G.M., Guimarães, E.F, Ichaso, C. L. F., Costa, C.G. \& Peixoto, A.L. 1978. Sistemática de Angiospermas do Brasil, Vol. 1. Livros Técnicos e Científicos, São Paulo, EDUSP.

Bentham, G. \& Hooker, J.D. 1883. Genera plantarum, Vol. 3. L. Reeve \& Co., London.

Brumitt, R.K. \& Powell, C. E. 1992. Authors of the plant names. Royal Botanic Gardens. Kew. 732p.

Cain, S.A. 1951. Fundamentos de Fitogeografia. ACME Agency. Buenos
Aires. 659p.

Câmara, I. de G. 1992-1993. In Cerrado, vastos espaços. Edições Alumbramento/ Livroarte Edit. 45-51 p.

Candolle, A.P. DC. 1868. Monimiaceae. Prodromus Systematis Naturalis Regni Vegetabilis 16 (2): 658-669.

Cavalcante, T.B. 1995. Revisão de Diplusodon Pohl (Lythraceae). Universidade do Estado de São Paulo, Instituto de Biociências. Tese de doutorado. $505 \mathrm{p}$.

Corner, E.H.J. 1976. The seeds of Dicotiledons, V. 1. Cambrigde Univ.Press. Cambridge. 311 p.

Corrêa, M.P. 1978. Dicionário das plantas úteis do Brasil e das exóticas cultivadas. Vol. IV: 158. Instituto Brasileiro de Desenvolvimento Florestal. Rio de Janeiro

Cronquist, A. 1981. An Integrated system of classification of flowering plants. Columbia Un Press., 1262 p.

Dias da Silva, R.A. 1926. Farmacopéia dos Estados Unidos do Brasil. Ed. Nacional, São Paulo. 554p.

Di Maio, F.R. 1996. Revisão taxonômica do gênero Hindsia Bentham (Rubiaceae, Hedyotideae). Arq. do Jard. Bot. Rio de Janeiro 34 (2):51-92.

Garrat, G.A. 1934. Systematic anatomy of the woods of the Monimiaceae. Trop. Woods 39: 18-44.

Gentry, A.H. 1986. Endemism in Tropical versus Temperate Plant Communities. In: M.E.Soule (ed.) Conservation Biology - The Science of Scarcity and Diversity. Cap. 8153-539. Sinauers Ass. Inc. Publ., Massachusetts.

Giulietti, A. M. 1971. Monimiaceae do Distrito Federal. Anais do Inst. Ci. Biol., Univ. Fed. Rur. Pernambuco 1(1): 97-106.

Giulietti, A. M., Menezes, N.L., Pirani,J.R., Meguro, M. \& Wanderley, M.G.L. 1987. Flora da Serra do Cipó, Minas Gerais: Caracterização e lista das espécies. Bolm. Botânica, Univ. S. Paulo. 9:1-151. 
Giulietti, A. M. \& Pirani, J. R. 1988. Patterns of geographic distribuition of some plant especies from the Espinhaço Range, Minas Gerais and Bahia, Brasil. In: Vanzolini, P.E. \& Meyer, W. R. (eds.) Proceeding of a Workshop on Neotropical distribution Patterns. Rio de Janeiro: Academia Brasileira de Ciências, 39-69 p.

Giulietti, A.M. \& Pirani, J.R. 1995. In: Flora of the Pico das Almas, Chapada Diamantina-Bahia, Brazil. Kew: Royal Botanic Garden. pp. 485-486.

Glaziou, A.F.M. 1913. Liste des Plantes du Brésil Central. Bull. Soc. Bot. France 59, Mem. 3g: 587.

Guedes-Bruni, R.R., Pessoa, S.V.A. \& Kurtz. B.C. 1996. Florística e estrutura do componente arbustivo-arboreo de um trecho preservado de floresta montana na Reserva Ecológica de Macaé de Cima. 127-145.In: Lima, H.C. \& Guedes-Bruni, R,R., Serra de Macaé de Cima: Diversidade florística e Conservação. 345p. Rio de Janeiro.

Harley, R.M. 1995. Flora of the Pico da Almas. Chapada Diamantina-Bahia, Brazil. Kew: Royal Botanic Garden. 831 p.

Hickey, L.J. 1973. Classification of the architeture of dicotyledonous leaves. Ann. J. Bot. 60 (1): 17-33.

Holmgren, P.K.; Holmgren, N.H. \& Barnet, L.C. 1990. Index Herbariorum, Part 1: The Herbaria os the World. New York Botanical Garden, New York. 693p

Hutchinson, J. 1964. Monimiaceae. In: The Genera of flowering plants. Angiospermae. Dicotiledones. $2^{\mathrm{a}}$ ed. Oxford, Univ. Press London. Vol. 1 (1): 110-123.

Jussieu, A.1. de. 1809. Mémoire sur les Monimiées, nouvel orde de plantes.Ann. Mus. Natl. Hist. Nat. 14: 116-135.

Kuhlmann, M. \& Kühn, E. 1947. Monimiaceae. In: A flora do distrito de Ibiti (ex- Monte Alegre) Município de
Amparo. Publ. Ser. B, Instituto de Botânica, Secr. Agric., São Paulo: p. 62 e p. 154

Lawrence, H.M. 1968. BotanicoPeriodicum-Huntiano. Hunt Botanical Library, Pittsburg. 1063 p.

Leitão, G.G., Simas, N.K., Soares, S.S.V., Brito, A.P.P., Claros, B.M.G., Brito, T.B.M. \& Monache, F.D. 1999. Chemystry and pharmocology of Monimiaceae: a special focus on Siparuna and Mollinedia. J. of Ethnopharm. 65: 87-102.

Lemée, A. 1932. Dic. Descr. Syn. Gen. Pl. Phan. 4: 242.

Lima, M.P. M. de, Guedes-Bruni, R,R., Sylvestre, L.S., Pessoa, S.V. et Andreata, R.H.P. 1997. Padrões de distribuição geográfica das espécies vasculares da Reserva Ecológica de Macaé de Cima. 103-123. In: Lima, H. C. \& GuedesBruni,R. R. (eds). Serra de Macaé de Cima: Diversidade Florística e Conservação em Mata Atlântica. Rio de Janeiro.

Lorence, D. H. 1985. A Monograph of the Monimiaceae (Laurales) in Malagasy Region (South-West Indian Ocean). Ann. of the Missouri Botanical Garden. 72 (1): 1-165.

Meguro, M., Pirani, J.R., Mello-Silva, R. \& Giulietti, A. M. 1996. Estabelecimento de matas ripárias e capões nos ecossistemas campestres da Cadeia do Espinhaço, Minas Gerais. Bolm. Bot., Univ. S. Paulo, 15: 1-11.

Money, L. L., Bailey, I.W. \& Swamy, B.G.L. 1950. The morphology and relationships of the Monimiaceae. J. Arnold Arbr. 31: 372-403

Pax, F. 1891. Monimiaceae. In: Engler, H. \& Prantl, K. (eds.), Die Natürlichen Pflanzenfamilien ... 3, 2: 94-105.

Peixoto, A.L. 1976.Monimiaceae do Brasil. O gênero Hennecartia Poisson. Bradea 2(13): 71-77. 
Peixoto, A.L. 1979. Contribuição ao Conhecimento da Seção Exappendiculate Perkins do Gênero Mollinedia Ruiz et Pavon (Mollinedieae, Monimioideae, Monimiaceae). Rodriguesia 50: 135222.

Peixoto, A.L. 1983. Monimiaceae. In: Flora Fanerogâmica da Reserva do Parque Estadual das Fontes do Ipiranga (São Paulo, Brasil). Hoehnea 10: 28-32

Peixoto, A.L. 1987. Revisão taxonômica do gênero Mollinedia Ruiz et Pavon (Monimiaceae, Monimioideae). Tese de Doutorado. Univ. Estadual de Campinas. 392p.

Peixoto, A.L. \& Pereira-Moura, M.V.L. 1996. Monimiaceae In: Lima, M.P.M. \& Guedes-Bruni, R. (eds.) Reserva Ecológica de Macaé de Cima, Nova Friburgo, RJ. Aspectos Florísticos das Espécies Vasculares. IBGE/JBRJ. p.299331.

Peixoto, A.L., Reitz, R., \& Guimarães, E.F. (ined.a) Monimiaceae.In: Reitz, R. Flora Ilustrada Catarinense. 80p.

Peixoto, A.L., Pereira-Moura, M.V.L. \& Santos, I.S. (ined.b) Monimiaceae. In: Flora Fanerogâmica do Estado de São Paulo. 41p.

Perkins, J. 1898. Beiträge zur kenntnis der Monimiaceae. I. Über die Gliederung der Gattungen der Mollinedieae. Bot. Jahrb. Syst. 25:547-577.

Perkins, J. 1911. Monimiaceae. In: A. Engler (ed.), Das Pflanzenreich ... 4, 101 (Nactrage): 1-67.

Perkins, J. \& Gilg, E. 1901. Monimiaceae.In: A. Engler (ed.). Das Pflanzenreich 4, 101: 1-122.

Pereira, M.V.L. 1991. Taxinomia e Morfologia das espécies do gênero Siparuna Aublet (Monimiaceae) ocorrentes no estado do Rio de Janeiro. Dissertação de Mestrado. Museu Nacional, UFRJ. 232 p.

Phillipson, W.R. 1980. A revision of Levieria (Monimiaceae). Blumea 26: 373-385.
Pirani, J.R. Giulieti, A. M. Mello-Silva, R. \& Meguro, M. 1994. Checklist and patterns of geographic distribution of vegetation of Serra do Ambrósio, Minas Gerais. Revta. Brasil. Bot. 17(2): 133-147.

Prance, G. T. 1972. An Ethnobotanical comparison of four tribes of Amazonian Indians. Acta Amazônica, Manaus. 2 (2): 7-27.

Prance, G.T. 1999. Conservation and monographic research on the flora of Tropical America. Biodiversity and Conservation 8: 1007-1015.

Record, S.J. \& Hess, R.W. 1943. Timbers of the New World. Yale Univ. Press, New Harven. 610 p.

Renner, S.R. 1998. Phylogenetic affinities of Monimiaceae based on cpDNA gene and spacer sequences. Perspectives in Plant Ecol., Evol. System. 1(1): 61-77.

Rizzini, C.T. 1979. Tratado de Fitogeografia do Brasil - Aspectos sociológicos e florísticos. Vol. 2. São Paulo. Huatec/ Edusp. 374 p.

Schodde, R. 1970. Two new suprageneric taxa in the Monimiaceae alliance (Laurales). Taxon 19 (3): 324-328.

Spix, J.B. von \& Martius, C.F.P. von. 1938. Reise in Brasilien. Müchen, Leipzig. (tradução em português, Ed. Imprensa Nacional) 3 volumes. 389, 567, 491 pags.

Stebbins, L. \& Major, J. 1965. Endemism and speciation in California Flora. Ecol. Monogr. 35: 1-35.

Stafleu, F.A. \& Cowan, R.S. 1979. Taxonomic Literature. Bohn, Scheltma \& Holkema. Utrecht. V. 2. 991 p.

Stelfelld, C.1955. As drogas vegetais da farmacopéia paulista. Tribuna Farmacêutica, Curitiba 23(6): 82-88.

Taubert, P. 1896. Beiträge zur Kenntnis des Centralbrasilians Staates Goyaz. Bot. Jahrb. Syst. 25: 427.

The Organization for Flora Neotropica. 1997. A guide for contributors to Flora Neotropica. 20p. 
Tulasne, L. R. 1855. Monographia Monimiacearum Arch. Mus. Hist. Nat. 8: 273-436.

Tulasne, L. R. 1857. Monimiaceae.In: Martius, C.F.P. von, Eichler A.W. \& Urban, I. Flora Brasiliensis ... München, Wien,. 4 (1): 290-327.

UICN. 1994. Categorias de las Listas Rojas de la UICN. Preparadas por la Comissión de Supervivencia de Especies de la UICN. Adoptadas por la $40^{\circ}$ Reunión del Consejo de la UICN, Gland, Suiza.

Urban, I. 1906. Vitae et itineraque collectorum botanicorum, notae collaboratorum biographicae, florae brasiliensis . In: Martius, C.F.P. von, Eichler, A.W. \& Urban, I. Flora Brasiliensis 1: 1-154.

Vattimo, I. de. 1957. Monimiaceae. In: Flora do Itatiaia I. Rodriguesia 20(32):56-61.

\section{Lista de Exsicatas em ordem alfabética dos sobrenomes dos coletores}

Atala, F. 328 (4) GUA, RB.

Barbosa, A. s.n (1) PNSO.

Barreto, R.A.A. 252 (1) RADAMBRASIL. Brade, A.C. 9942 (1) R; 9943 (2) R, RB.

Campos Porto, P. 2788 (1) RB; 3383 (1) RB. Campos, M.T.V.A. \& Souza, E.D.P. de s.n. (3) CFSC13432

Cardoso, D. s.n. (4) BHCB 3670.

Cordeiro I. et al. 1307 (1) SPFP, RBR; s.n. CFCR 11429 (3) RBR.

Cruz, N.D. da et al. 6352 (3) RB

Curran, H.M. 640 (2) MO.

França, J. \& Proença, C. 443 (3) UB, HEPH Gionotti, E. et al. 26708 (1) UEC.

Giulietti, A.M. et al. s.n. (1) SPF 107154, RBR; s.n - PCD 3488 (3) CEPEC, UB.

Glaziou, A.F.M., 4203 (1) BM, C; 17222 (1) C; 17769 (2) C; 18482(4) C, K; 20485 (2) BR, K; 22040 (3) C, K, RB.

Harley, R.M. et al., 24531 (3) UB, SPF, K; 25108 (3) RBR; 25816 (3) CEPEC; 25818 (3) UB, RB, CEPEC; 26140 (3) CEPEC,
RB; 26141 (3) RB, CEPEC; 27317 (3) CEPEC; 27318 (3) MO, UB, RB; 25460 (3) MO, SPF, RBR; 25112 (3) MO, SPF, RBR.

Heringer, E.P. et al. 30 (3) IBGE, 585 (3) IBGE.

Heringer, E.P. \& Herrenberger 13942 (3) NY, RBR, UB.

Irwin, H \& T. Soderstrom, T.R. 5966 (3) NY, $\mathrm{UB}, \mathrm{K}, \mathrm{Z}$.

Irwin, H.S. et al. ,8556 (3) NY, RBR, Z; 9610 (3) NY, R, RBR; 20092 (3).UB.

Leite, E. (S.J.) s.n. (1) FCAB; (1) FCAB 1970.

Lima, H.C. et al. , 3456 (2) RB, RBR; s.n. (2) RB 294100, RBR; s.n. (2) RB 294102, RBR.

Lombardi, J.A. 1842 (3) BHCB

Marcgraf, F. 10092 (1) RB, Z; 10456 (1) RB, $\mathrm{Z}$.

Mendonça, R.C. et al. 532 (3) IBGE, RB, UCE.

Pereira Neto, M \& Lopes, E.C. 313 (3) RB.

Pereira, B.A.S. 1421 (3) RBR.

Pessoa, S.V.A. et al. 504 (2) RB.

Pirani, J.R. s.n - CFCR 12446 (3) RBR.

Pires, J.M. et al. 9547 (3) UB.

Proença, C. \& Bean, M.F. 504 (1) UB, $\mathrm{HEPH}$

Ramos, E. 557 (3) HEPH.

Ratter, J.A. et al. 3585 (3) MO, NY, UB; 3907 (3) NY, UB, K.

Robim, M.J. 321 (1) SPF, RBR, 314 (1) SPF, RBR

Sano, P.T. s.n. CFCR 14708 (3) SPF.

Santos, I. S \& P. Germano Filho 24 (3) RBR; 25 (3) RBR; 27 (3) RBR; 28 (3) RBR; 20

(3) RBR; 21 (3) RBR; 32 (3) RBR; 33

(3) RBR; 35 (3) RBR; 43 (3) RBR; 51

(3) RBR; 53 (1) RBR; 54 (1) RBR; 56

(1) RBR; 59 (1) RBR.

Santos, I.S. et al. 22 (3) RBR; 60 (1) RBR; 62 (1)RBR; 63 (1) RBR; 64 (3) RBR; 65 (3) RBR; 66 (3) RBR; 67 (3) RBR; 68 (3) RBR.

Sarti, S.J. 22 (1) FCAB.

Schwacke, C.A.G., 25 (1) R; 1920 (1) R, 
RB; 7465 (4) RB, BHCB; s.n. (4) RB

42511; 9404 (4) RB; 10.388 (4) RB; 12353

(4) RB; s.n. (4) RB 42506

Silva, F. et al. 175 (3) HEPH.

Silvestre, L.S. et al. s.n. (2) RB 294112.

Tamashiro, J.Y. et al. 867 (1) ESA, RBR.

Ule, E. 747 (3) R; 2441 (4) R.

Vidal, J. 5400 (1) R.

Walter, B.M.T. 2245 (3) CEN, IBGE, R. 
